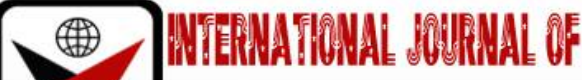

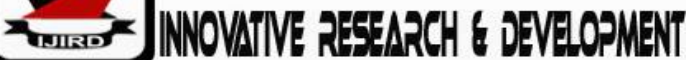

ISSN 2278-0211 (Online)

\section{The Role of Governance, Education and International Community on Peace Building in South Sudan: A Case Study of Juba County, South Sudan}

\author{
Dr. Gabriel Alier Riak Achot \\ Associate Professor, Department of Political Science \\ Upper Nile University, South Sudan
}

\begin{abstract}
:
The study focused on role of Government, Education and international communities on Peace building in South Sudan. It assessed the role of government, education and international communities on peace building in South Sudan. The objectives of the study were to; examine the relationship between the role of Governance and Peace building, relationship between Education, International communities and Peace building, Governance and international communities and Peace building and study the factor structure on Governance, Education and International communities on Peace building.

The research design was across- sectional and descriptive and using both qualitative and quantitative approaches in collecting data from the study population totaling 225respondents. Sampling technique was used to select the sample of 183 respondents from the employees of the three NGOs and community members of Juba County. Data was analyzed using descriptive analysis option of SPSS version (18.0), and was then presented using Spearman's correlation, multiple regression and factor structure loadings of the relationship and prediction for Governance, Education, International communities and Peace building.

The major findings of the study were that there is a significant positive correlation between; Governance and Peace building ( $r=0.391$, P-value < 0.01), Governance and Peace building ( $r=0.391$, P-value $<0.01)$, Governance and international communities and Peace building ( $r=0.188, P$-value $<0.01)$ and between Governance, Education and International communities on Peace building ( $r=0.391,0.188,0.1888, P$-value $<0.01)$

The study recommends that leaders in Juba county and South Sudan as a whole, should try to embrace a democratic governance that which promotes good values such as participation, accountability, responsiveness, transparency and rule of law leads to effective peace building in a society so as to build sustainable peace, the international community must commit in providing capacity building, foreign aid, demobilization of the military forces and institutional reform, International communities should promote and advocate for a democratic governance and an effective education system. Peace building should be about supporting the transformative processes and these changes should unfold over generations.
\end{abstract}

Keywords: The Influence of governance, education, international community, peace building

\section{Introduction and Background to the Study}

This chapter presents the introduction, back ground of the study, problem statement, purpose of the study, general and specific objectives, research questions, scope of the study, significance of the study and the conceptual frame work.

\subsection{Introduction}

The people of South Sudan have historically known more war than peace. For the past 4 generations, citizens have only known war as a result of conflict, and this pattern will continue until an alternative way arises. South Sudanese believe now that they are their own nation, it's time to teach people how to solve conflict using a different means other than guns. It's time to teach a way of peace (Pact Sudan Country Program, 2010).

Currently, there are little to no resources on peace building available to the South Sudanese. Schools and churches do not have the tools, processes, or activity training they need to teach healthy conflict resolution and encourage sustainable peace. In addition to the lack of peace building tools, there are few trained South Sudanese people who are leading peace building efforts (Pact Sudan Country Program, 2010).

Even after the signing of the CPA in 2005, communities have continued to conflict over resources, political differences and border disputes 
The signing of Sudan's Comprehensive Peace Agreement in 2005 provided unprecedented opportunities for peace building and improving the humanitarian and development situation. However, a lack of peace dividends for conflict-affected communities in border areas has perpetuated tensions based on resources (MDGIF, 2012). An absence of social services and livelihood opportunities, and perceptions of isolation and marginalization all contribute to undermining durable peace in the border areas, where poverty rates are up to $90 \%$. Continued armed fighting, pressures on grazing and water resources and struggles over land rights contribute to instability (MDGIF, 2012).

In South Sudan, international stakeholders like the African Union (AU), the United Nations (UN) and the European Union (EU) have been investing significant financial resources through multiple humanitarian assistance programmes and rehabilitation and (re)construction projects, as well as economic stabilization, human rights monitoring, education and empowerment for political participation initiatives.

Maio2009contends that although external efforts from international communities have been proven to be necessary in conflict-ridden societies, they are not sufficient to safeguard peaceful relationships or resolve the strategic problems challenging development; local peace-builders are indispensable to this process. Developing and engaging mechanisms to manage conflict challenges, especially in the aftermath of conflict, entail multifarious political, economic and socio-cultural processes aimed at continuous efforts to: address the conflict relations in a non-violent manner; moderate violence and mitigate the chances of relapse into conflict or its escalation; build harmonious, tolerant relationships; and build and support existing capacity for the enhancement of sustainable peace and development in the longer-term (Schirch, 2008). These processes are necessary to promote peace and stability and involve multi- dimensional and multi-sectoral undertakings of infrastructural (re)construction, (re)building institutions and endeavours to reconcile differences that will establish collaboration between communities and groups (Lederach, 2003). At the heart of conflict transformation and peace-building, therefore, is the need not only to understand the root causes of the conflict and engage in constructive change processes, but also (and most importantly), to build healthy relationships between the warring factions, as well as between the state and the society. This, in turn, can help define and foster coordinated efforts capable of enabling change in the structures of violence and achieving sustainable peace and development in the longer term (Pflanz, 2012). The current study tries to investigate how asset- based approaches, social services development and capacity development influences peace building in post conflict transitioning societies in South Sudan.

This section therefore presents the introduction, back ground of the study, problem statement, purpose of the study, general and specific objectives, research questions, scope of the study, significance of the study and the conceptual frame work.

\subsection{Background to the Study}

\subsubsection{Governance}

Governance refers to "all processes of governing, whether undertaken by a government, market or network, whether over a family, tribe, formal or informal organization or territory and whether through laws, norms, power or language (Mark, 2013)." It relates to processes and decisions that seek to define actions grant power and verify performance. UNDP, 2006 defines governance as the exercise of political, economic and administrative authority in the management of a country's affairs at all levels. For UNDP governance "comprises the complex mechanisms, processes and institutions through which citizens and groups articulate their interests, mediate their differences and exercise their legal rights and obligations. Union Development Agency, defines governance as the ability and capacity of a government to fulfill its mission. According to Brinkerhoff, the design and implementation of governance reforms in post-conflict states target three areas; reconstituting legitimacy, re-establishing security and rebuilding effectiveness. According to Orr, (2002) a government is essential to providing security, justice, economic, and social functions and to channeling the will, energies, and resources of both the indigenous population and the international community. Good governance is related to a set of values such as participation, accountability, responsiveness, transparency and rule of law by (Brandi, 2008).

\subsubsection{Education}

Education is the means by which successive generations develop the values, knowledge and skills for their personal health and safety and for future political, economic, social and cultural development (Jan, 2002).Education is an important driver of social development and can also contribute to transformations through other sectors within postconflict societies in terms of changing behaviours and attitudes to violence, policing and the legal system; to a better understanding of the political system, how it operates and its implications for local communities; to the development of skills that support economic regeneration and sustainable livelihoods; and to changing social relations between groups or dealing with the legacies of conflict. These are all important peace building challenges that need to be initiated early and sustained over time (Robinson, 2006). Education is measured using attributes such as; (Change of attitude, imparting positive values, enhancing knowledge and skills and Awareness about human rights) that were proposed by (Smith and Vaux, 2003).

\subsubsection{International Community}

The term international community refers to intergovernmental organizations (IGOs), multilateral and bilateral agencies, international nongovernmental organizations (NGOs) and relief agencies. Those in the international community involved in promoting electoral processes in post-conflict countries (UNDP, 2006). In post-conflict societies is it much advocated by the international community that democratic systems provide the best mechanisms for reconciliation and are the best guarantors of lasting peace. International communities are measured basing on Tschirgi, (2010) using 
attributes like (Monitoring of the peace agreement, Disarmament, Demobilization of ex-combatants, Demilitarization and integrating human development) as adapted from (UNDP, 2006)

\subsubsection{Peace Building}

Peace building is the capacity to conceive of and engender meaningful responses that are capable of resolving the incidence of violence and its recurrence in society. It is the long-term transformation of a war system into a peace system. This requires constructive changes in the personal, structural, relational and cultural aspects of conflict over the short, medium and long terms (Miall 2004). According to Hassan 2009, peace building is a term used to encompass a range of activities which aim to prevent, alleviate, or resolve conflict. In general, peace building aims at addressing the underlying causes of conflict and creates institutional and socioeconomic structures which promote lasting peace. On the other hand, Afako (2003) describes the term of peace building as a concept which covers a wider area and, along term scale. Its aim is a change in the social structures underlying the conflict, and a change in the attitudes of the parties to the conflict. Gurr and Barbara (2009) try to define the term peace building as a full spectrum of intervention that is focused on restoring relations between groups that have been in conflict, as such peace building involves a number of different aspects which may include forgiveness, cooperation, negotiation, mediation, facilitation, creation of mutual understanding, and/or reconciliation. While Kirya (2003) tries to describe the term peace building as series of events by saying peace building is not a specific event but it is all processes that occur before, during and after violent conflicts. He also says peace building is not a specific activity but it consists of consequences of various activities. Lederach 2005 peace-building as a structural process that allows the transformation of conflict to take place at three key levels of leadership, namely: top-level leadership (top-down approach); middle-level leadership (middle-out approach); and grassroots-level leadership (bottom-up approach).

Juba County where the research will be undertaken is an administrative area in Central Equatoria state, South Sudan. It is the largest county in Central Equatoria and one of the largest in the entire region of Equatoria. Its county seat is Juba, the state capital of Central Equatoria and the national capital of the Republic of South Sudan. Its population according to the disputed 2008 census conducted by the Republic of the Sudan, prior to South Sudanese independence, was 372,413 (Vuni, 2009). In Juba County there is conflict fueled by competition over scarce resources, high numbers of returnees and internally displaced people, armed non-state actors and recurrent cross-border tensions between nomadic tribes and local communities has resulted in widespread instability and violence in communities along the Sudan-South Sudan border (IOM Mission in South Sudan, 2013).To foster peace-building and stability in the high-risk areas of Juba County, the European Union Instrument for Stability and IOM have initiated the Peace and Stability Quick Impact Fund Grants Program (PSQIF) in the county, working in partnership with local NGOs and Community-Based Organizations (CBOs) (ibid). The overall objective of PSQIF is to provide quick, flexible and visible peace-building and stabilizing interventions that will help to create an environment for peaceful coexistence among communities in the county, aiming to deter the outbreak of future conflict while strengthening mutual confidence and trust among community members (Vuni, 2009).

\subsection{Statement of the Problem}

Peace building requires sustained international support for national efforts across the broadest range of activities - monitoring ceasefires; demobilizing and reintegrating combatants; assisting the return of refugees and displaced persons; helping organize and monitor elections of a new government; supporting justice and security sector reform; enhancing human rights protections and fostering reconciliation after past atrocities (DESA, 2012).

Countries in transition face difficult choices when deciding how to deal with the violence and conflict of their past in a way that increases their chances of a better, conflict-free, future. The transition may be from armed conflict to a peaceful state (e.g. Burundi, Mozambique, Rwanda and Sierra Leone), from dictatorship to democracy (e.g. Argentina and Chile), or a combination of both, as was the case in South Africa (Moghalu, 2009). Francis 2000 argues that 'peace agreements...do not in themselves end wars or bring about lasting peace. In most cases, pre-war conditions and the war mentality jeopardize the prospects of a consolidated peace and post-war reconciliation. The fact that half of all peace accords tend to fail within the first five years, the so-called conflict trap, highlights the need to address the root causes of conflict in order to prevent a recurrence. According to Reychler2001 peace- building mechanisms is challenged in some cases because, in the process of transformation, some conflicts are transformed in a constructive and reciprocally satisfactory manner, while others end up frustrating one or all of the parties involved in the conflict.

There have been weak institutions and poor economic management and weak institutions are in part a result of weak leadership which has eventually caused the precarious separation of the South and by extension the current crisis of governance. This has been coupled with weak education systems and pressures on International communities from both the government and the rebels hence a decline in peace building programmes (Wilson Center, 2014).

This study will emphasize that peace building must lead to sustained international support for national efforts across the broadest range of activities - monitoring ceasefires; demobilizing and reintegrating combatants; assisting the return of refugees and displaced persons; helping organize and monitor elections of a new government; supporting justice and security sector reform; enhancing human rights protections and fostering reconciliation after past atrocities in agreement with (DESA, 2012).

\subsection{Purpose of the Study}

To assess the role of government, education and international communities on peace building in South Sudan 


\subsection{Specific Objectives}

- To examine the relationship between the role of Governance and Peace building

- To examine the relationship between Education, International communities and Peace building

- To examine the relationship between Governance and international communities and Peace building

- To study the factor structure of Governance, Education and International communities on Peace building.

\subsection{Research Questions}

- What is the relationship between Governance and Peace building?

- What is the relationship between Education, International communities and Peace building?

- What is the relationship between Governance and international communities on Peace building?

- What is the factor structure of Governance, Education and International communities on Peace building?

\subsection{Scope of the Study}

\subsubsection{Subject Scope}

The study focused on the role of Government, Education and international communities on Peace building.

\subsubsection{Geographical Scope}

The study was carried out in Juba County in South Sudan with the employees from NGOs that included UNICEF,

UNHCR and UNDP and community members from the county.

\subsubsection{Time Scope}

The study reviewed documents from 2006-2013. The research was carried out between May and October 2014.

\subsection{Significance of the Study}

- Academic contribution: It provided baseline information for further research in International relations and conflict resolutions.

- The study broadened the research her's skills in identifying the underlying factors that affect the role government, education and international communities in peace building.

- Government leaders and managers of International organisations learnt from the research and improve on strategy formulation and implementation as a modality for attaining peace in South Sudan.

- Government contribution: Results of the study benefited policy makers and beneficiaries in organizations by providing information on the role of government, education and international community which can be used in building peace in South Sudan.

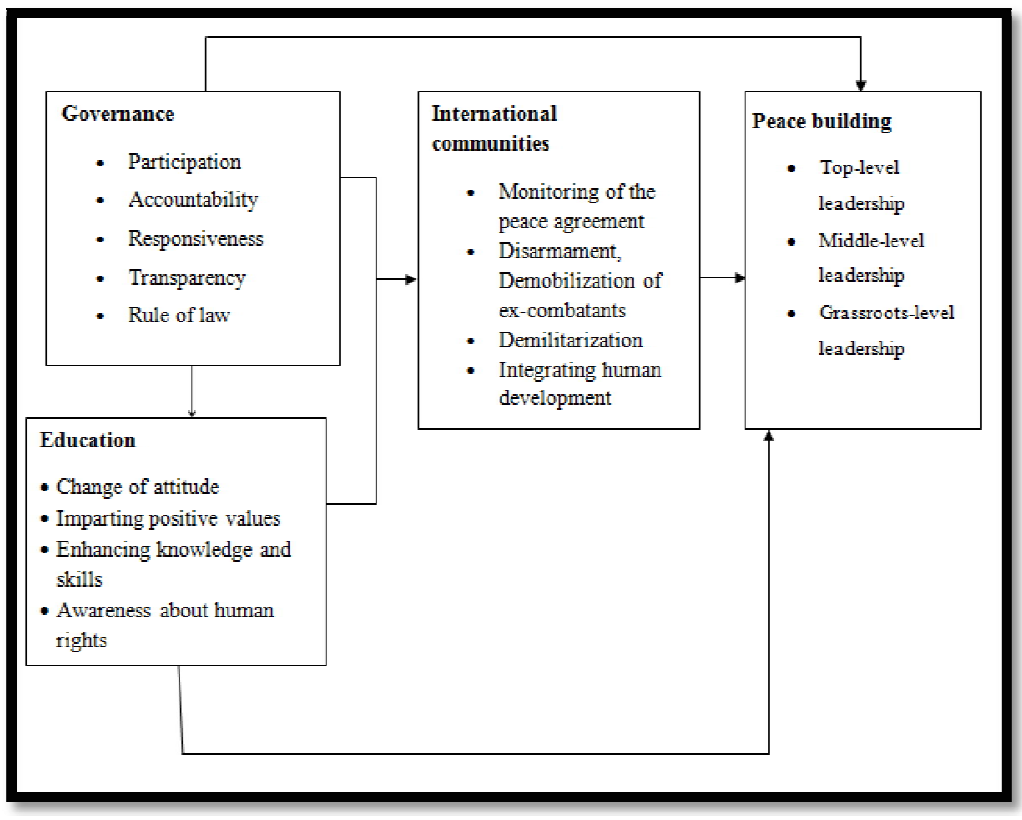

Figure 1: Conceptual Frame Work

\subsubsection{Description of the Model}

Governance was measured using participation, accountability, responsiveness, transparency and rule of law that were used by (Brandi, 2008); Education was measured using attributes such as; (Change of attitude, Imparting positive values, Enhancing knowledge and skills and Awareness about human rights)that were proposed by(Smith, 2003);The role of International community's was measured basing on (Tschirgi, 2010)using attributes like (Monitoring of the peace agreement, Disarmament, Demobilization of ex-combatants, Demilitarization and integrating human development) as adapted from (UNDP, 2006) and Peace building was measured using Top-level leadership (top-down approach), Middle- 
level leadership (middle-out approach) and Grassroots-level leadership (bottom-up approach) by John Paul Lederach 2005 Model for Peace building.

\section{Literature Review}

\subsection{Introduction}

This section reviews the existing literature put forward by different scholars and personalities on the role of government, Education and international communities on peace buildings well as the relationship among the three variables.

\subsection{The Relationship between the Role of Governance and Peace Building}

\subsubsection{Governance}

For the European Union and UNDP 2006, the quality of governance is ultimately attributed to its democratic content. Thereby the promotion of 'democratic governance' is a core element in their development assistance strategy. UNDP argues that human development and governance are inseparable. From the human development perspective UNDP has stated that 'good governance' is 'democratic governance. According to Brandi 2008, Democratic Governance is the glue that holds all the other development priorities set out across the MDG's Together. In post-conflict societies is it much advocated by the international community that democratic systems provide the best mechanisms for reconciliation and are the best guarantors of lasting peace.

According to Orr 2002, a government is essential to providing security, justice, economic, and social functions and to channeling the will, energies, and resources of both the indigenous population and the international community. According to Ngware \& Kironde 2010, governments support peace building through encouraging institutional participation in peace building and democratic process of their countries.

According to Ngware \& Kironde 2010, the government's role to peace building is by ensuring that its legitimacy and credibility are intimately tied to a transparent and representative process of policy making by a council of democratically elected community leaders that enjoys legal recognition as an established corporate entity. According to the author, it this is achieved, leaders are likely to be respected and trusted and this can help to bridge divergent interests and ideas which are fundamental for peace building. Addison and Murshed 2001 pointed out that sustainable peace building can be achieved by governments if they develop ability to touch the daily lives of citizens through improved delivery of services. The authors believe that an important characteristic of effective local government is its proximity to the recipients of the basic services it provides. Thus, if government is well-recognized for its role in providing basic infrastructure such as drinking water, waste management, construction of latrines and public convenience facilities, recreational facilities and parks, and local roads, it is likely to unite people to work together for peace.

Amara (2009) noted that the government can also ensure peace by strengthening public participation for peace building. Good governance is related to a set of values such as participation, accountability, responsiveness, transparency and transparency by Brandi \& Clara, (2008).

\subsubsection{Participation}

Participation approaches may be adopted to foster and institutionalize elements of good governance. In this situation, inclusive participation and representation, transparency and accountability, and capacity for local dispute resolution are seen not as simply means to fulfill immediate needs but also as ends in themselves (Silverman, 2005). There is some evidence to support links between community-based interventions and progress in governance (World Bank, 2006). Government should be able to allow participation of all the citizens in all the activities.

\subsubsection{Accountability}

Accountability is the process whereby public sector entities, and the individuals within them, are responsible for their decisions and actions, including their stewardship of public funds and all aspects of performance and submit themselves to appropriate external scrutiny. It is achieved by all parties having a clear understanding of those responsibilities, and having clearly defined roles in a robust structure. Both internal and external accountability and reporting structures are attributes of sound financial management (Zahra and Filatochev, 2004). King 2002 made a distinction between accountability and responsibility by stating that one is liable to render an account when one is accountable and one is liable to be called to account when one is responsible. Accountability, therefore, is enforced by law, policy or statute and responsibility by conduct and a positive relationship with its stakeholders. King 2002also referred to the latter as Social Responsibility.

\subsubsection{Responsiveness}

This refers to the willingness to help the public and provide prompt service (Swar and Sahoo, 2012). Responsiveness is a core value of the transformed public service. Its application in practice will have a profound effect on the way national departments and provincial administrations operate. The key to implementing the responsiveness principle lies in being able to identify quickly and accurately when services are falling below the promised standard and having procedures in place to remedy the situation (Johnson,1995). 


\subsubsection{Transparency}

This is required to ensure that stakeholders can have confidence in the decision-making processes and actions of public sector entities, in the management of their activities, and in the individuals within them. Being open by means of meaningful consultation with stakeholders and communication of full, accurate and clear information leads to effective and timely action and lends itself to necessary scrutiny. King 2002also referred to transparency as the independence of information without dominance of a particular viewpoint. Governments cannot be effective without the transparent disclosure of accurate information to all the various stakeholders (compare White Paper on Transforming Public Service Delivery, 1997).

\subsubsection{5.. Rule of Law}

Rule of law is an approach that brings together the police, civil society and local communities to jointly take responsibility for and develop solutions to local safety and security. The country's laws have to be adopted and respected for de-mining and weapons collection. De-mobilized combatants have to be involved in de-mining as a way to facilitate local reintegration (USAID, 2007). This approach articulates peace building in post conflict transitioning societies.

\subsubsection{Peace Building}

Spence 2001 defined peace building as those activities and processes that: focus on the root causes of the conflict, rather than just the effects; support the rebuilding and rehabilitation of all sectors of the war-torn society; encourage and support interaction between all sectors of society in order to repair damaged relations and start the process of restoring dignity and trust; recognize the specifics of each post conflict situation; encourage and support the participation of indigenous resources in the design, implementation and sustainment of activities and processes; and promote processes that will endure after the initial emergency recovery phase has passed.

Lederach's 2005look at Peace building as the capacity to conceive of and engender meaningful responses that are capable of resolving the incidence of violence and its recurrence in society. It is the long-term transformation of a war system into a peace system. This requires constructive changes in the personal, structural, relational and cultural aspects of conflict over the short, medium and long terms (Miall, 2004). For Galtung, Peace building involves addressing and removing the root causes of violence the structural and (a later addition to his work) the cultural violence - that feeds into and enables direct violence. The goal of peace building is positive, sustainable peace (Andy, 2003)

Andy also emphasizes the importance of local knowledge, ownership and participation in peace building. In 2007, the Secretary-General's Policy Committee provided a "conceptual basis for peace building to inform UN practice," defining peace building as follows: Peace building involves arrange of measures targeted to reduce the risk of lapsing or relapsing into conflict by strengthening national capacities at all levels for conflict management, and to lay the foundations for sustainable peace and development (UN,2007).

Lederech visualizes peace-building as a structural process that allows the transformation of conflict to take place at three key levels of leadership, namely: top-level leadership (top-down approach); middle-level leadership (middle-out approach); and grassroots-level leadership (bottom-up approach) (Pillay, 2006). This process aims to describe how peace should be built within the conflict-affected population, that is - "how the house of peace should be built" in war-torn societies (Isike \& Okeke, 2010).

Isike\&Okeke2010 recognizes the potential, importance, legitimacy, uniqueness, and interdependency of the needs and resources of civil society in their own peace-building processes, and promotes coordination across all levels and activities. As stated by Miall 2004 the model also broadens the view of the conflict and the conflict parties and indicates the scope for drawing peace- building resources from the wider society. It hinges on the fact that building mutual relationships is a pivotal part of the peace-building process. It credits the role of indigenous actors from within the conflict society and empowers and supports local efforts by engaging groups in different peace-building activities. Thus, this model of peacebuilding as proposed by Lederach seeks to bring civilians together through building trust; it requires and promotes intergroup communication, interaction and cooperation. There should be an integrated and analytical framework of the processes and goals of conflict transformation and peace-building, in both theory and practice. Peace building is measured using Top-level leadership (top-down approach), Middle-level leadership (middle-out approach) and Grassroots-level leadership (bottom-up approach).

\subsubsection{Top-level Leadership (Top-Down Approach)}

The top level consists of key political and military leaders, religious leaders with a high visibility in the conflict. These focus on high level negotiations, emphasize cease fire lead by a highly visible single mediator. They can be accessed by mediation at the level of states, which is advantageous for peace negotiations (Mischnick, 2007); (World Bank, 2006).

\subsubsection{Middle-Level Leadership (Middle-Out Approach)}

The middle level is made up of ethnic and religious, intellectuals and humanitarian leaders who are highly respected in society and who may be in formal leadership positions in sectors such as education, business or health or may be members of ethnic or religious groups within a community. The middle level leaders can be engaged through activities such as problem-solving workshops or peace commissions and insider partial teams with the assistance of renowned local individuals in society (Mischnick, 2007). 


\subsubsection{Grassroots-Level Leadership (Bottom-Up Approach)}

The grassroots level represents the majority of the population or the masses, and includes leaders who operate on a day-to-day basis, like leaders of a local NGO or a refugee camp, local health officials; they can be reached through a wide range of peace-building approaches such as local peace commissions, community dialogue projects, or trauma healing, prejudice reduction and psychological work in post war trauma (World Bank, 2006); (Paffenholz \& Spurk, 2006).

Governance is another area that has to be addressed within peace building. Long-term security extends beyond reforming military and police forces and is also contingent upon the conversion of warring factions into political parties that can work to manage conflicts in a manner that is conducive of positive change (Kirsti Samuels, 2005). Peace building operations are susceptible to breakdown when societies have a poor governance framework that exacerbates social fault lines, aggravates divisions and tensions, entrenches conflict, or provides a basis to contest the government. Governance in peace building designs requires the development of institutional capacities such as the judiciary, the electoral system, and other agencies that work to advance policy reforms, enhance transparency, and increase representation and accountability (Kirsti Samuels, 2005). For example, in many peace building contexts, plans for elections are often outlined, agreed upon and signed into the peace agreements between opposing factions.

\subsection{The Influence of the Role of Governance and International Communities on Peace Building.}

\subsubsection{International communities}

The term international community refers to intergovernmental organizations (IGOs), multilateral and bilateral agencies, international nongovernmental organizations (NGOs) and relief agencies. Those in the international community involved in promoting electoral processes in post-conflict countries (UNDP, 2006).The international community can support capacity-building of political parties in a number of areas including; the dialogues between parties on electoral reform and other issues; integrating human development and gender equality principles into internal party activities and platforms; internal operations of parties (fundraising, campaign planning, candidate selection and training); long-term capacity development; media outreach; and specific initiatives women, youth and political party finance. An important role which can be played by international actors in post-conflict societies is to mediate with the different political parties so that they do not defect from the democratization process and return to war (UNDP, 2007).

The role of international community I peace building is measured using Monitoring of the peace agreement, Disarmament, Demobilization of ex-combatants, Demilitarization and integrating human development.

\subsubsection{Monitoring of the Peace Agreement}

Outside actors can assist in the monitoring of the peace agreement - this is important when spoilers (leaders or parties whose vital interests are threatened by peace implementation) might try "undermine the agreement and reduce the expected utility of a negotiated settlement for all parties. According to Doyle and Sambanis 2006, states that if spoilers are present in a peace process, peacekeepers can keep the peace only if they can exercise some degree of enforcement by targeting the spoilers and preventing them from undermining the negotiations.

The international community should be able to allow moderates limited spoilers with specific stakes and greedy opportunists to "act like peacemakers in the peace process without fearing reprisals from total spoilers who are unalterably opposed to the peace settlement. Doyle and Sambanis 2006 case-studies suggest that to manage spoilers effectively, "peacekeepers should avoid acquiring a reputation for weakness.

\subsubsection{Disarmament, Demobilization}

Another area where the international community can play an important role is in the Disarmament, Demobilization and Reintegration (DDR) of ex-combatants. This action is imperative in the transition from war to peace. In post-conflict societies this is a complex process as different fighting groups are divided by animosities and face a real security dilemma as they give up their weapons, when civil society structures have crumbled, and when the economy is stagnant (Lyons \& Terrence, 2004). The short-term goal of DDR is the restoration of security and stability - through progressive disarmament the mistrust that a fuels security dilemma fighting factions will reduce, allowing "aid workers to intervene more effectively, and allows peaceful social and economic activities to resume. The long-term goal of DDR is "the sustained social and economic reintegration of ex- combatants into a peaceful society. To strengthen DDR, opportunities must be created for those leaving their armed groups, through social and economic development (Lyons \& Terrence, 2004).

\subsubsection{Demilitarization}

It is also important to demilitarize politics so that processes of war termination and democratization are successful. According to Lyons "demilitarize politics entails building norms and institutions that bridge the structures of wartime based on violence, predation and fear (such as militias, black markets and chauvinistic identity groups) to arrangements based on security to trust that can sustain peace and democracy (like political parties, open economies and civil society (UNDP, 2002).

\subsubsection{Integrating Human Development}

International community must contribute to the strengthening of civil society, civil culture, and social capital as all are important for strengthening democracy and enabling conflict resolution. But we must be cautious in this statement. Robert Putnam in Bonding his book Bowling Alone distinguishes between 'bonding' and 'bridging' social capital, "and only 
the latter unambiguously supports democratization" social capital develops when you get involved with people like yourself and bridging social capital is when you become involved with people who are less like you. Bridging social capital can be as simple as joining a neighborhood association. For post-conflict countries, developing bridging social capital is essential as through dialogue people of different faiths or ethnicity can develop trust and toleration - critical values for the building of democracy and for resolving conflict. According to the UNDP, (2002), participatory processes can increase efficiency and economic sustainability, particularly for projects requiring community involvement. Participation implies a process of empowerment and effective citizens.

For the European Union and UNDP 2006, the quality of governance is ultimately attributed to its democratic content. Thereby the promotion of 'democratic governance' is a core element in their development assistance strategy which contributes to peace building. UNDP argues that human development and governance are inseparable. From the human development perspective UNDP has stated that 'good governance' is 'democratic governance. According to Brandi 2008, Democratic Governance is the glue that holds all the other development priorities set out across the MDG's Together (Brandi, 2008). In post-conflict societies, it is much advocated by the international community that democratic systems provide the best mechanisms for reconciliation and are the best guarantors of lasting peace. Good governance and support from international communities increase higher chances of peace building in the society (Brandi, 2008).

According to Orr 2002 a government is essential to providing security, justice, economic, and social functions and to channeling the will, energies, and resources of both the indigenous population and the international community which improve peace building in the society.

\subsection{The Relationship between Education, International Communities and Peace Building}

\subsubsection{Education}

Education is a fundamental right that should be maintained at all times, even in the most difficult circumstances. This is not simply an ideological statement. Where education is maintained in the midst of conflict it may provide an important mechanism for the protection of children against abuse; Education is an essential tool for human development and eradication of poverty; Education can be part of the problem as well as part of the solution. Policies and practice at all levels within the education system need to be analyzed in terms of their potential to aggravate or ameliorate conflict (Smith and Vaux,2003). In situations where violent conflict already exists education may have a protective role, for example, by providing points of stability and daily routine for children if it is possible to keep schools functioning, by helping understand underlying causes of conflict and by strengthening messages within society about the negative impacts of violence. It is a means of educating people about other, non-violent ways of responding to conflict. In situations where peace processes are underway, education may also be a means of contributing to social transformation, for example, through reforms to the education system itself and by educating people about new arrangements for political representation, justice and policing. Education is also the most powerful tool to develop the economic and social skills necessary to generate sustainable livelihoods for successive generations. Education is the fundamental tool that makes institutional change in other sectors possible by educating personnel currently in post or those who will shape future institutions. The role of education is measured using Change of attitude, imparting positive values, Enhancing knowledge and skills and Awareness about human rights.

\subsubsection{Change of Attitude}

If learners' attitudes towards other groups change/become more tolerant, conflict can be prevented. Personal attitudes will only change if structural inequalities are also addressed and education. Education has an important role to play in identifying underlying causes for conflict related to social justice. It also has a role to play in helping new generations understand why conflict took place and in dealing with its legacies (Anderson and Mendenhall, 2006). There will be a need for education to address social and cultural issues related to fundamental freedoms within broader society. These could involve programmes that address, for example, the role of the media and media independence, religious freedoms and attitudes to expressions of cultural identity.

\subsubsection{Imparting Positive Values}

Education programmes should consist of imparting positive values and modes of behavior based on non-violence and respect for fundamental human rights. In order to build a culture of peace it is necessary to include the full participation of and empowerment of women, men and youth, an atmosphere of understanding, tolerance and solidarity, sharing and free exchange of useful information, using nonviolent means to manage conflict and the replacement of violent competition with cooperation (Mazurana \& Mckay, 2004).

\subsubsection{Enhancing Knowledge and Skills}

Education in emergencies can provide protection from violence, particularly for girls, schools can help to protect from recruitment and exploitation (Nicolai,2005); in terms of survival skills and knowledge such as landmine awareness and protection from HIV and AIDS and providing opportunities for psychological, emotional and cognitive development. Education is also the most powerful tool to develop the economic and social skills necessary to generate sustainable livelihoods for successive generations (Kirk, 2008). 


\subsubsection{Awareness about human rights}

Zedriga 2006 states that violence normally affects all gender and members of a community; but the most affected group more often than not is the women or children. These are often abducted, raped or defiled and turned into sex slaves, combatants, orphans and widows, denied basic and fundamental rights as a result of the violence. For Mazurana and Mckay2004, education should aim at sensitizing women and the whole community on recognizing and enforcing their human rights. There should increase access to information by the population on available opportunities for increasing welfare, income and land rights.

Brinkerhoff, Derick 2005 argues that conflict interventions need a rehabilitative dimension oriented to the past, a resolutive dimension oriented to the present, and a preventive dimension oriented to both present and future. Doyle and Sambanis, 2006 have designed the Peace building Triangle which illustrates the peace-building space, after civil war, in terms of local capacity, hostility and international capacity. According the 'triangle model' "the probability that peace building will succeed is a function of a country's capacity for peace, the available international assistance, and the depth of war-related hostility. The Peace Building Triangle suggests that to combat hostility the international community must commit in providing capacity building, foreign aid, demobilization of the military forces and institutional reform.

International assistance and effective coordination in these areas stimulates parties favoring the peace agreement to meet their commitments and thereby diminishes the possibility of hostility. In most cases it is important for the international community to commit with international peacekeepers, whose presence can "deter defections from the peace treaty (Doyle and Sambanis, 2006).

Stedman, 2008 in his publication Implementing Peace Agreements in Civil Wars: Lessons and Recommendations for Policymakers identified several determinants of successful implementation for peace agreements which range from identifying the number of soldiers; the presence of hostile neighboring states or networks; to the commitment of the international community. Education is an important driver of social development and can also contribute to transformations through other sectors within post-conflict societies in terms of changing behaviors and attitudes to violence, policing and the legal system; to a better understanding of the political system, how it operates and its implications for local communities; to the development of skills that support economic regeneration and sustainable livelihoods; and to changing social relations between groups or dealing with the legacies of conflict. These are all important peacebuilding challenges that need to be initiated early and sustained over time.

\subsection{The Factor Structure of Governance, Education and International Communities on Peace Building.}

Crucially, education is not a marginal player in peace building, but a core component of building sustainable peace. Peace building is essentially about supporting the transformative processes any post-conflict society needs to go through, and these changes unfold over generations. Developments through the education sector represent a very important part of this transformative process, with huge potential to impact positively or negatively. The education sector is potentially a very important sector for supporting the transformative process in post-conflict societies (Stedman, 2008).

The recent Global Monitoring Report 2011 from the United Nations Educational, Scientific and Cultural Organization (UNESCO) called for an increased role for education and governance for peace building. Similarly, the World Bank's World Development Report (WDR) 2011 recognized the important contribution to peacebuilding that the education sector and governance could make. However, the two reports differ in opinions on when educational interventions should be prioritized, with the GMR arguing for early engagement and prioritization of education throughout all conflict phases, while the WDR suggested that security and elections be prioritized in the immediate post-conflict period with education receiving less priority until the medium-term post-conflict phase. These debates feed into broader discussions within the international community on the role of social services (including education) in peacebuilding, and provide part of the background rationale for this research.

Access to a quality education is regarded as a right that should be maintained even in the most difficult circumstances. In the midst of conflict, it can provide knowledge and skills that provide protection, while in the longer term, it can provide values and attitudes that offer a basis for transforming conflict itself and all this good governance policies lead to success of peace building (Stedman, 2008).

\section{Methodology}

\subsection{Introduction}

This section presents the methods employed in data collection and analysis. It describes the research design, study population, sampling method, sample size, data collection tools, and data processing and analysis.

\subsection{Research Design}

The research design was across- sectional and descriptive and using both qualitative and quantitative approaches. Quantitative approach was employed using questionnaires. This was mainly used to quantify and analyze the data in order to get in depth understanding of how the variables under study impact sustainable development and Qualitative tools was mainly the interview and observation which was used in the research because of necessity to arrive at the in-depth conclusions about the relationships of the study. 


\subsection{Research Population}

The research population of 225 included 85 NGO staffs from their main headquarters in Juba County and 140 community members. The researcher clustered the NGOs population to 35 UNDP staff, 25 UNICEF Staff and UNHCR Staff as elaborated in the table below;

\begin{tabular}{|c|c|}
\hline Category/Stratum & Population Size(N) \\
\hline UNDP staff & 35 \\
\hline UNICEF staff & 25 \\
\hline UNHCR staff & 25 \\
\hline Community members & 140 \\
\hline Total & $\mathbf{2 2 5}$ \\
\hline
\end{tabular}

Table 1: Population

Source: Primary Data

\subsection{Sample Size}

The sample size was calculated using Krejcie and Morgan table for determining sample size (1970) as this gives a practical ratio according to the population size. According to Krejcie and Morgan table approximately 183 respondents was used as a sample size of the entire population of 225. The researcher clustered this population to 32 UNDP staff, 24 UNICEF staff, 24 UNHCR staff and 103 community members as elaborated in the table below;

\begin{tabular}{|c|c|c|}
\hline Category/Stratum & Population Size(N) & Sample Size \\
\hline UNDP staff & 35 & 32 \\
\hline UNICEF staff & 25 & 24 \\
\hline UNHCR staff & 25 & 24 \\
\hline Community members & 140 & 103 \\
\hline Total & 225 & 183 \\
\hline
\end{tabular}

Table 2: Sample Size

Source: Primary Data

\subsection{Sampling Procedure}

The researcher used both probability and non-probability sampling techniques so as to be exhaustive in the research findings. Random sampling was used as a probability technique to obtain a good representative sample of the area population of the residents. Random sampling which is simple random was used to pick mainly community members, community leaders and county officials. Non-probability sampling was mainly convenience sampling which was used to select NGO officials and politicians.

\subsection{Sources of Data}

Data sources include both primary and secondary sources (Amin, 2005). The researcher used both primary and secondary data sources.

\subsubsection{Primary Data}

The researcher gathered this data from the field through questionnaires, interviews and observation from the various respondents selected from the employees of the ministry and citizens that receive the services from the ministry.

\subsubsection{Secondary Data}

The researcher collected the data from printed materials such as books, reports and government journals from reliable sources which are used to further justify and confirm data gathering from the field.

\subsection{Techniques of Data Collection}

\subsubsection{Questionnaires}

The researcher used questionnaires as a data collecting instrument to obtain information from the community members, NGOs officials and community members from Juba County. The questionnaires were designed according to the theme and objectives of the research. They contained also close ended questions. The close ended questions were based on the 5- point Likert Scale format.

\section{$\underline{3.7 .2 .0 b s e r v a t i o n}$}

Observation as a research instrument was used to obtain the opinions of different respondents regarding the research gap during the interviews. The observation technique complemented questionnaire and interviews. Observation helped to view the workplace environment. 


\subsubsection{Interviews}

The interview is a conversation between two or more people where questions were asked by the interviewer to elicit facts or statements from the interviewee. The advantage of using interviews in this research was that it would make the research in-depth and collection information that would have been missed by the questionnaire and observation.

\subsection{Validity and Reliability of Research Instruments}

To ensure the validity and reliability of the instrument, the researcher employed expert judgment method. After constructing the questionnaire, the researcher contacted experts in this area to go through it to ensure that the instrument is clear, relevant, specific and logically arranged. Also, a pre-test was conducted in order to test and improve on the reliability and validity of the instrument. Cronbach's Alpha test was employed to measure the reliability.

Content validity index (C.V.I) was used to establish the validity of the questionnaire. C.V.I was measured as items rated 3 or 4 by both judges divided by the total number of items in the questionnaire (Oso \& Onen, 2005).

\begin{tabular}{|c|c|c|c|}
\hline Variable & Anchor & $\begin{array}{c}\text { Cronbach Alpha } \\
\text { Coefficient }\end{array}$ & $\begin{array}{c}\text { CVI (Content Validity } \\
\text { Index) }\end{array}$ \\
\hline Governance & 5 point & 0.8870 & 0.7516 \\
\hline Education & 5 point & 0.8629 & 0.8403 \\
\hline International communities & 5 point & 0.8387 & 0.7266 \\
\hline Peace building & 5 point & 0.7338 & 0.6133 \\
\hline
\end{tabular}

Table 3: Reliability of the Instrument Variable

Source: Primary Data

Since the Cronbach Alpha coefficients for all the study variables were above 0.50 as indicated in Table 3 above, it implies that the scales used to measure the study variables were consistent and therefore reliable and meeting acceptance standards for the research. This is also similar with the sighting of (Sekyawa, 2009).

\subsection{Measurement of the Variables}

- Governance was measured using a 5-point Likert Scale from 1 (strongly disagree) to 5 (strongly agree) basing on (Candless, 2010), an approach to community building; and the attributes include Sensitization program, Democracy and transparency, Dialogue and reconciliation, Provision of basic services and Support to economic revitalization.

- Education was measured using a 5-point Likert Scale from 1 (strongly disagree) to 5 (strongly agree) basing on (Smith and Vaux, 2003) that measures Education's role in peace building with Change of attitude, imparting positive values, Enhancing knowledge and skills, Awareness about human rights and Conflict resolution and peace building skills.

- International communities were measured using a 5-point Likert Scale from 1 (strongly disagree) to 5 (strongly agree) basing on (Tschirgi, 2010) and the attributes include; Behavior change, Organizing dialogue meetings, Social network, Capacity building and Financial support.

- Peace building was measured using a 5-point Likert Scale from 1 (strongly disagree) to 5 (strongly agree) basing on John Paul Lederach Model for Peace building, (2005) that used Top-level leadership (top-down approach), Middle-level leadership (middle-out approach) and Grassroots-level leadership (bottom-up approach) for measuring peace building.

\subsection{Data Analysis}

The data was collected from the field; it was coded, edited and analyzed using descriptive analysis options of SPSS version (18.0). The descriptive approach was used for qualitative forms of data. The data was presented using Spearman's correlation's statistical techniques which were used to test and establish whether there exists a relationship between the role of governance, Education, International communities and Peace building while multiple regression analysis was used to test the potential predictors of the dependent variable.

\subsection{Ethical Considerations}

The researcher ensured that all citations and references of different authors are acknowledged. The researchermaintained confidentiality of the respondents and protected their privacy at all times. The researcher tried to be professional when presenting herself to the respondents as this could affect the attitude and expectations of the respondents. The researcher used the language that was as neutral as possible regarding the terminology involving people and avoided discriminative language. Lastly, the researcher tried to be considerate during the interactions with respondents. Informed consent was sought from the respondent before any interview.

\subsection{Limitations of the Study}

Limitations that might be faced by the researcher include;

- Attrition; some respondents filled in the questionnaires without really reading or understanding the question but just to complete fast. The researcher however made an effort to avoid distributing questionnaires or holding interviews during rush hours and also try to capture the interest of the respondents. 
- Sensitivity of information; some respondents felt that the information required was sensitive and could affect their working environment if revealed since it was concerned with security issues. The researcher however made an effort to convince respondents that the information exchanged was very confidential.

- Unwillingness to fill the questionnaires; some respondents were unwilling to share information about their leaders, supervisors, benefactors, workmates and the service system. The researcher however endeavored to emphasize that it was a purely academic research and confidentiality would be upheld.

- Interpretation of the questions affected the meaning because some respondents got difficulty in interpreting the questions correctly because of the high levels of illiteracy. However the researcher tried to interpret the questions for them where necessary.

\section{Presentation and Intepretation of Study Findings}

\subsection{Introduction}

This chapter presents bio data, relationship between the role of Governance and Peace building; Education, International communities and Peace building; Governance and International communities and Peace building, regression analysis and factor structure of all variables.

\subsection{Respondents' Bio Data}

The total response rate was 183 respondents.

\subsubsection{Gender of Respondents}

The Table 4 presents gender of respondents.

\begin{tabular}{|c|c|c|}
\hline Gender & Frequency & Percent/\% \\
\hline Male & 118 & 64.5 \\
\hline Female & 65 & 35.5 \\
\hline Total & 183 & 100.0 \\
\hline
\end{tabular}

Table 4: Gender by Respondent Distribution

Source: Primary Data

The Table 4 above shows that $64.5 \%$ were males while $35.5 \%$ were females.

\subsubsection{Age Group of the Respondents}

Table 5below presents the age of respondents.

\begin{tabular}{|c|c|c|}
\hline Age & Frequency & Percent/\% \\
\hline $31-40$ & 64 & 34.9 \\
$41-50$ & 53 & 28.9 \\
\hline $21-30$ & 36 & 19.7 \\
$50+$ & 30 & 16.5 \\
\hline Total & 183 & 100.0 \\
\hline
\end{tabular}

Table 5: Age of the Respondents

Source: Primary Data

Table 5 above shows that $34.9 \%$ of the participants belonged in the age group of $31-40,28.9 \%$, belonged in the age group of 41-50 years and $19.7 \%$ belonged in the age group of $21-30$ while $16.5 \%$ belonged in the age group of 50 and above years.

\subsubsection{Marital Status of the Respondents}

Table 6 below presents marital status of respondents.

\begin{tabular}{|c|c|c|}
\hline Marital Status & Frequency & Percent/\% \\
\hline Married & 80 & 43.7 \\
\hline Single & 68 & 37.2 \\
Separated & 25 & 13.6 \\
Divorced & 10 & 5.5 \\
\hline Total & 183 & 100.0 \\
\hline
\end{tabular}

Table 6: Marital Status of Respondents

Source: Primary Data

Table 6 above shows that $43.7 \%$ of the participants were married, 37.2\% were singles and $13.6 \%$ had separated from their spouses while the remaining $5.5 \%$ were divorced. 


\subsubsection{Number of Biological Children}

Table 4.4 below presents the number of Biological children

\begin{tabular}{|c|c|c|}
\hline Number of Children & Frequency & Percent/\% \\
\hline $1-3$ & 66 & 36.1 \\
\hline $4-5$ & 63 & 34.4 \\
\hline 0 & 33 & 18.0 \\
\hline $5+$ & 21 & 11.5 \\
\hline Total & 183 & 100.0 \\
\hline
\end{tabular}

Table 7: Number of Biological Children for the Respondents

Source: Primary Data

Table 7 above shows that $36.1 \%$ of the respondents had $1-3$ children, $34.4 \%$ of the participants had $4-5$ children and $18 \%$ had no children while $11.5 \%$ of the participants had $5+$ children.

\subsubsection{Number of Dependants of the Respondents.}

\begin{tabular}{|c|c|c|}
\hline Number of Dependants & Frequency & Percent/\% \\
\hline $1-3$ & 68 & 37.2 \\
\hline $4-6$ & 63 & 34.4 \\
\hline 0 & 31 & 16.9 \\
\hline $5+$ & 21 & 11.5 \\
\hline Total & 183 & 100.0 \\
\hline
\end{tabular}

Table 8: Number of Dependants for Respondents

Source: Primary Data

Table 8 below presents number of dependants for the respondents.

Table 8 above shows that $37.2 \%$ of the respondents had 1-3 dependants, $34.4 \%$ of the participants had $4-6$ dependants and $16.9 \%$ had no dependants while $11.5 \%$ of the participants had $5+$ dependants.

\subsubsection{Level of Education}

The Table 9 below presents the level of education of the respondents

\begin{tabular}{|c|c|c|}
\hline Level of Education & Frequency & Percent/\% \\
\hline Degree & 64 & 34.9 \\
\hline Diploma & 42 & 22.9 \\
\hline Certificate & 31 & 16.9 \\
Secondary & 25 & 13.7 \\
Primary & 21 & 11.6 \\
\hline Total & 183 & 100.0 \\
\hline
\end{tabular}

Table 9: Level of Education

Source: Primary Data

Table 9 above shows that $34.9 \%$ of the respondents were Degree holders, $22.9 \%$ of the respondents were Diploma holders, $16.9 \%$ of the participants had certificates and $13.9 \%$ were had studied up to secondary level while the remaining $11.6 \%$ of the respondents had studied up to Primary level.

4.2.7. Number of years the respondents had stayed in Juba County

The Table 10 below presents the number of years the respondents had stayed in Juba County

\begin{tabular}{|c|c|c|}
\hline Length of stay (Years) & Frequency & Percent/\% \\
\hline $6+$ & 65 & 63.1 \\
\hline $4-6$ & 23 & 22.4 \\
\hline $2-4$ & 10 & 9.7 \\
$1-2$ & 5 & 4.8 \\
$<1$ & 0 & 0.0 \\
\hline Total & 103 & 100.0 \\
\hline
\end{tabular}

Table 10: Number of Years the Respondents Had Stayed in Juba County

Source: Primary Data

The Table 10 above shows that $63.1 \%$ had stayed in Juba County for $6+$ years, $22.4 \%$ had stayed in Juba County for 4-6 years, 9.7\% had stayed there for 2-4 years and $4.8 \%$ had stayed there for 1 - 2 years and none of the respondents had been Juba County for less than a year. 


\subsubsection{Number of Years Spent Working with the Ngos}

The Table 11below presents the number of years spent working with the NGOs

\begin{tabular}{|c|c|c|}
\hline Length of Stay (Years) & Frequency & Percent $/ \%$ \\
\hline $4-6$ & 40 & 50.0 \\
\hline $6+$ & 20 & 25.0 \\
\hline $2-4$ & 10 & 12.5 \\
$1-2$ & 6 & 7.5 \\
$<1$ & 4 & 5.0 \\
\hline Total & 80 & 100.0 \\
\hline
\end{tabular}

Table 11: Number of Years the Respondents Had Spent Working with the Ngos

Source: Primary Data

The Table 11 above shows that 50\% had worked for the NGOs for 4-6 years, $25 \%$ had worked for the NGOs for over six years, $12.5 \%$ had worked for there for $3-4$ years and $7.5 \%$ had worked for $1-2$ years while the remaining $5 \%$ had worked with the NGOs for less than a year.

\subsection{Relationship between Study Variables}

Pearson correlation coefficient was used to determine the degree of relationship between the study variables as presented in Table 12 below

\begin{tabular}{|c|c|c|c|c|}
\hline & $\mathbf{1}$ & $\mathbf{2}$ & $\mathbf{3}$ & $\mathbf{4}$ \\
\hline Governance (1) & 1.000 & & & \\
\hline Education (2) & $.873^{* *}$ & 1.000 & & \\
\hline International communities (3) & $.285^{* *}$ & $.624^{* *}$ & 1.000 & \\
\hline Peace building (4) & $.391^{* *}$ & $.188^{* *}$ & $.188^{* *}$ & 1.000 \\
\hline
\end{tabular}

Table 12: Pearson's Zero Order Correlation Matrix

** Correlation Is Significant at the .01 Level (2-Tailed).

Source: Primary Data

\subsubsection{The Relationship between Governance and Peace Building}

The results in Table 12 indicated a significant positive relationship between Governance and Peace building ( $\mathrm{r}=0$. 391 , P-value $<0.01$ ). This implied that good governance which promotes good values such as participation, accountability, responsiveness, transparency and rule of law leads to effective peace building in a society.

\subsubsection{The Relationship between Education, International Communities and Peace Building}

The results in Table 11 indicated a significant positive relationship between Education, International communities and Peace building $(\mathrm{r}=0.188, \mathrm{P}$-value $<0.01)$. This implied that education effected through change of attitude, imparting positive values, enhancing knowledge and skills and awareness about human rights plus the support of international communities which through monitoring of the peace agreement, disarmament, demobilization of ex-combatants, demilitarization and integrating human development all greatly contributed to peace building in a country like South Sudan.

\subsubsection{The Relationship between Governance and International Communities and Peace Building}

The results in Table 12 indicated a significant positive relationship between Governance and international communities and Peace building $(\mathrm{r}=0.188$, P-value $<0.01)$. This implied that when there is good governance which advocates for good values such as participation, accountability, responsiveness, transparency and rule of law leads to effective peace building in a society; with the support from International communities, then peace building in any country can be possible.

\subsection{4 .The Factor Structure on Governance, Education and International Communities on Peace Building}

Table 12 above shows an influence of Governance, Education and International communities on Peace building ( $\mathrm{r}$ $=0.391,0.188,0.1888, \mathrm{P}$-value $<0.01$ ) which indicates that for peace building to be possible in any society, there must be good governance, a strategic education system and support from international communities delivered through monitoring of the peace agreement, disarmament, demobilization of ex-combatants, demilitarization and integrating human development. A strategic education system is an important because it can act as a driver of social development and can also contribute to transformations through other sectors within post-conflict societies in terms of changing behaviours and attitudes to violence, policing and the legal system in the society.

\subsection{Regression Analysis}

Regression analysis was used to examine the level to which Governance, Education, and International communities determine Peace building. 


\begin{tabular}{|c|c|c|c|c|c|}
\hline \multirow[t]{2}{*}{ Model } & \multicolumn{2}{|c|}{$\begin{array}{l}\text { Unstandardized } \\
\text { Coefficients }\end{array}$} & \multirow{2}{*}{$\begin{array}{c}\begin{array}{c}\text { Standardized } \\
\text { Coefficients }\end{array} \\
\text { Beta }\end{array}$} & \multirow[b]{2}{*}{$\mathbf{T}$} & \multirow[b]{2}{*}{ Sig } \\
\hline & B & Std. Error & & & \\
\hline Constant & -5.735 & 108.362 & & -.053 & .966 \\
\hline Governance & .691 & .955 & .506 & .723 & .601 \\
\hline Education & .598 & .996 & .397 & .601 & .656 \\
\hline International communities & -.174 & .672 & -.186 & -.259 & .838 \\
\hline
\end{tabular}

Table 13: Below Shows the Regression Model for Governance, Education, International

Communities and Peace Building

$R$ - Square $=0.584$, Adjusted $R$ - Square $=0.665, F=0.468$, Sig $=0.760$

Source: Primary Data

Table 13 shows a linear relationship between Governance, Education and International communities on Peace building $(\mathrm{F}=0.468$, Sig $=0.760)$. Governance, Education and International communities greatly explained with Peace building.

Governance (Beta $=0.506$ ) explained more to Peace building, followed by Education (Beta $=0.397$ ) and International communities (Beta $=-0.186$ ). This implied that for peace building to be effective in any society, good governance, good education and support from international communities must be advocated for. This is because when there is when there is good governance that promotes participation of citizens in all national programmes, accountability of civil servants, and responsiveness for all servants, transparency in all government departments plus rule of law; then education is possible and with the support from international communities, then peace building is easily achieved.

\subsection{Factor Loadings of Governance, Education, International Communities and Peace Building}

This research used factor loading in order to check how much a variable load into its corresponding factor. To understand how each item is loaded into its relevant principal component we use Table 12 for the factor loading of each item. Straub 2004 suggests to us that value of each item in factor loading should be at least 0.40 into its relative principal component.

\subsubsection{Factor Analysis Results of Governance}

\begin{tabular}{|c|c|c|c|c|}
\hline Variables & Participation & Accountability & Demilitarization & $\begin{array}{c}\text { Integrating } \\
\text { Human } \\
\text { Development }\end{array}$ \\
\hline $\begin{array}{c}\text { Government should be able } \\
\text { to allow participation of all } \\
\text { the citizens in all the } \\
\text { activities. }\end{array}$ & 0.970 & & & \\
\hline $\begin{array}{c}\text { All stakeholders' } \\
\text { participation helps in peace } \\
\text { building in the society } \\
\text { There is inclusive } \\
\text { participation and } \\
\text { representation of all the } \\
\text { stakeholders }\end{array}$ & 0.951 & 0.899 & & \\
$\begin{array}{c}\text { Because of the government } \\
\text { initiatives, citizens have } \\
\text { started living together in a } \\
\text { harmony and peaceful } \\
\text { environment }\end{array}$ & & & & \\
\hline $\begin{array}{c}\text { International communities } \\
\text { have strengthened } \\
\text { opportunities for those } \\
\text { leaving their armed groups. } \\
\text { There has been social and } \\
\text { economic development of the } \\
\text { ex-combatants }\end{array}$ & & & 0.933 & \\
$\begin{array}{c}\text { Disarmament, demobilization } \\
\text { and reintegration is } \\
\text { imperative in the transition } \\
\text { from war to peace }\end{array}$ & & 0.886 & & \\
\hline
\end{tabular}


Arrangements based on

security to trust that can

sustain peace and democracy have been made

There has been building norms and institutions that

bridge the structures of wartime based on violence Dialogue between people of different faiths ethnicity can develop trust and toleration have been organized

There has been an increase of efficiency and economic sustainability, particularly for projects requiring community involvement International communities have helped in the process of empowerment and effective

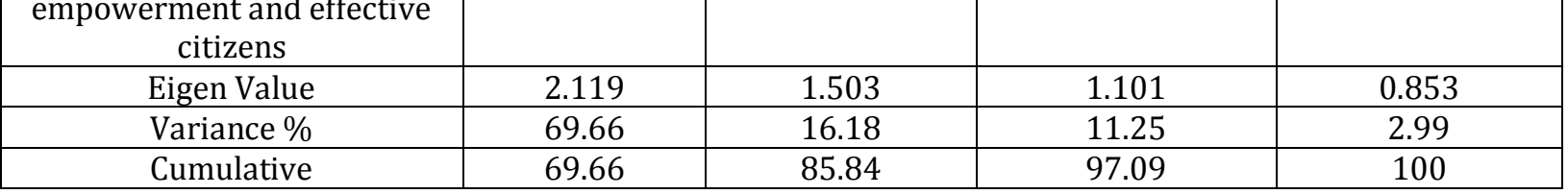

Table 14: Factor Loadings of Governance Source; Primary Data

Table 14above shows how the factor loadings do confirm that Governance is measured by Participation, Accountability, Demilitarization and Integrating human development as hypothesized in the conceptual model in Figure 1.1

\subsubsection{Factor Analysis Results of Education}

\begin{tabular}{|c|c|c|c|c|}
\hline Variables & $\begin{array}{l}\text { Change of } \\
\text { Attitude }\end{array}$ & $\begin{array}{c}\text { Imparting } \\
\text { Positive } \\
\text { Values }\end{array}$ & $\begin{array}{c}\text { Enhancing } \\
\text { Knowledge and } \\
\text { Skills }\end{array}$ & $\begin{array}{c}\text { Awareness } \\
\text { about Human } \\
\text { Rights }\end{array}$ \\
\hline $\begin{array}{c}\text { Peoples' attitudes towards other groups } \\
\text { have been changed and are more } \\
\text { tolerant to each other Education has } \\
\text { addressed the social and cultural issues } \\
\text { related to fundamental freedoms within } \\
\text { broader society } \\
\text { Education has helped the new } \\
\text { generations understand why conflict } \\
\text { took place and in dealing with its } \\
\text { legacies } \\
\text { Education has imparted positive values } \\
\text { and modes of behavior based on non- } \\
\text { violence } \\
\text { There has been a good atmosphere of } \\
\text { understanding, tolerance and solidarity, } \\
\text { sharing and free exchange of useful } \\
\text { information, } \\
\text { There has been full participation of and } \\
\text { empowerment of women, men and } \\
\text { youth }\end{array}$ & $\begin{array}{l}0.993 \\
0.988 \\
0.976\end{array}$ & $\begin{array}{l}0.902 \\
0.832 \\
0.638\end{array}$ & & \\
\hline
\end{tabular}




\begin{tabular}{|c|c|c|c|c|}
\hline $\begin{array}{l}\text { Education can provide protection from } \\
\text { violence, particularly for girls } \\
\text { Education instills survival skills and } \\
\text { knowledge such as landmine awareness } \\
\text { and protection from HIV and AIDS } \\
\text { Education is also the most powerful } \\
\text { tool to develop the economic and social } \\
\text { skills necessary to generate sustainable } \\
\text { livelihoods for successive generations } \\
\text { Education has been aiming at } \\
\text { increasing awareness on income and } \\
\text { land rights. } \\
\text { Education has increased access to } \\
\text { information by the population on } \\
\text { available opportunities for increasing } \\
\text { welfare } \\
\text { Education has saved affected group } \\
\text { more often than not is the women or } \\
\text { children }\end{array}$ & & & $\begin{array}{l}0.973 \\
0.899 \\
0.680\end{array}$ & $\begin{array}{l}0.982 \\
0.923 \\
0.680\end{array}$ \\
\hline Eigen Value & 1.690 & 0.992 & 0.062 & 0.027 \\
\hline Variance \% & 62.583 & 34.147 & 2.282 & 0.988 \\
\hline Cumulative & 62.583 & 96.730 & 99.012 & 100 \\
\hline
\end{tabular}

Table 15: Factor Loadings of Education Source; Primary Data

Table 15 above shows how the factor loadings do confirm that Education is measured by Change of attitude, imparting positive values, Enhancing knowledge and skills and Awareness about human rights as hypothesized in the conceptual model in Figure 1

\subsubsection{Factor Analysis Results of International Communities}

\begin{tabular}{|c|c|c|c|}
\hline Variables & $\begin{array}{c}\text { Monitoring } \\
\text { of the Peace } \\
\text { Agreement }\end{array}$ & $\begin{array}{c}\text { Disarmament, } \\
\text { Demobilization }\end{array}$ & Demilitarization \\
\hline $\begin{array}{c}\text { Outside actors can assist in the monitoring of the } \\
\text { peace agreement } \\
\text { Due to sensitizations, citizens have started living in } \\
\text { harmony and peaceful environment } \\
\text { Sensitization programmes help in peace building in } \\
\text { the society } \\
\text { Because of sensitization, the citizens have been able to } \\
\text { unite after the conflict }\end{array}$ & $\begin{array}{l}0.868 \\
0.815 \\
0.788 \\
0.723\end{array}$ & & \\
\hline $\begin{array}{l}\text { International communities have played an important } \\
\text { role is in the disarmament, demobilization and } \\
\text { reintegration of ex-combatants. } \\
\text { International communities have strengthened } \\
\text { opportunities for those leaving their armed groups. } \\
\text { There has been social and economic development of } \\
\text { the ex-combatants } \\
\text { Disarmament, demobilization and reintegration is } \\
\text { imperative in the transition from war to peace }\end{array}$ & & $\begin{array}{l}0.830 \\
0.801 \\
0.772 \\
0.718\end{array}$ & \\
\hline $\begin{array}{l}\text { There has been building norms and institutions that } \\
\text { bridge the structures of wartime based on violence } \\
\text { Arrangements based on security to trust that can } \\
\text { sustain peace and democracy have been made } \\
\text { International communities have empowered civil } \\
\text { societies }\end{array}$ & & & $\begin{array}{l}0.790 \\
0.752 \\
0.728\end{array}$ \\
\hline Eigen Value & 2.001 & 1.433 & 0.654 \\
\hline Variance \% & 75.324 & 17.215 & 7.461 \\
\hline Cumulative & 75.324 & 92.539 & 100 \\
\hline
\end{tabular}

Table 16: Factor Loadings of International Communities

Source; Primary Data 
Table 16above shows how the factor loadings do confirm that International communities is measured by International communities, Imparting positive values, Disarmament, Demobilization and Demilitarization as hypothesized in the conceptual model in Figure 1

\subsubsection{Factor Analysis Results of Peace Building}

\begin{tabular}{|c|c|c|c|}
\hline Variables & $\begin{array}{c}\text { Top-level } \\
\text { Leadership }\end{array}$ & $\begin{array}{l}\text { Middle-level } \\
\text { Leadership }\end{array}$ & $\begin{array}{c}\text { Grassroots- } \\
\text { Level } \\
\text { Leadership }\end{array}$ \\
\hline $\begin{array}{l}\text { Involvement of key political and military leaders, } \\
\text { religious leaders always emphasize cease fire } \\
\text { because of the involvement of NGOs } \\
\text { Through the involvement of NGOs key parties } \\
\text { always focus on high level negotiations } \\
\text { Through the involvement of NGOs negotiations are } \\
\text { always led by a highly visible single mediator } \\
\text { Through the involvement of NGOs negotiations } \\
\text { have always been accessed by mediators at the } \\
\text { level of states }\end{array}$ & $\begin{array}{l}0.868 \\
0.802 \\
0.776 \\
0.713\end{array}$ & & \\
\hline $\begin{array}{c}\text { Peace commissions have always been organized by } \\
\text { NGOs for reconciliation in the societies. } \\
\text { Problem-solving workshops have always been } \\
\text { organized for reconciliation } \\
\text { Ethnic, religious, intellectuals and humanitarian } \\
\text { leaders have contributed to reconciliation } \\
\text { Insider partial teams with the assistance of } \\
\text { renowned local individuals in society have always } \\
\text { been organized }\end{array}$ & & $\begin{array}{l}0.811 \\
0.788 \\
0.726 \\
0.694\end{array}$ & \\
\hline $\begin{array}{c}\text { Community dialogues organized by NGOs have } \\
\text { been organized to help in reconciliation and peace } \\
\text { building in the societies } \\
\text { Projects for trauma healing have been used by } \\
\text { NGOs in reconciliation and peace building in the } \\
\text { societies. } \\
\text { Through the involvement of NGOs there have been } \\
\text { local peace commissions for reconciliation and } \\
\text { peace building of the societies. } \\
\text { The population or the masses represented by } \\
\text { leaders of local NGOs }\end{array}$ & & & $\begin{array}{l}0.804 \\
0.775 \\
0.744 \\
0.696\end{array}$ \\
\hline Eigen Value & 1.830 & 0.943 & 0.437 \\
\hline Variance $\%$ & 70.691 & 22.552 & 6.757 \\
\hline Cumulative & 70.691 & 93.243 & 100 \\
\hline
\end{tabular}

Table 1 7: Factor Loadings of Peace Building Source; Primary Data

Table 17above shows how the factor loadings do confirm that Peace building is measured by Top-level leadership, Middle-level leadership and Grassroots-level leadership as hypothesized in the conceptual model in Figure 1.1.

\section{Interpretation of the Findings}

\subsection{Introduction}

This chapter of the research report presents interpretation of the study findings. It is comprised of two major sections which include the respondents' bio data and objectives of the study.

\subsection{Bio Data}

\subsubsection{Gender of the Respondents}

Out of 183 respondents, $64.5 \%$ were males while $35.5 \%$ were females. The high percentage of male respondents was attributed to the fact that the men are more educated than the women in the Country.

\subsubsection{Age Group of the Respondents}

Out of 183 respondents, $34.9 \%$ of the participants belonged in the age group of 31-40, 28.9\%, belonged in the age group of $41-50$ years and $19.7 \%$ belonged in the age group of $21-30$ while $16.5 \%$ belonged in the age group of 50 and above years. 
This distribution of respondents by age is an indication that most of the respondents are mostly of adult age, independent and productive and this explains the reason as to why the number of respondents was increasing with increase in age. The information got from this study can be relied on since most of the respondents were adults that can reason independently.

\subsubsection{Marital Status of the Respondents}

Out of 183 participants, $43.7 \%$ of the participants were married, $37.2 \%$ were singles and $13.6 \%$ had separated from their spouses while the remaining $5.5 \%$ were divorced.

This implied that most of the respondents in the study were married people with responsibility; it's a sign of respect in whatever they do and during research, this showed high degree of ownership.

\subsubsection{Number of Biological Children}

Out of 183 participants, $36.1 \%$ of the respondents had $1-3$ children, $34.4 \%$ of the participants had $4-5$ children and $18 \%$ had no children while $11.5 \%$ of the participants had $5+$ children.

This research finding shows that most of the respondents had dependants and big families to take care of. Therefore, however productive they could be, the dependants drained. The big percentage of dependants was attributed to high unemployment levels in the country.

\subsubsection{Number of Dependents of the Respondents}

Out of 135 participants, $37.2 \%$ of the respondents had 1-3 dependants, $34.4 \%$ of the participants had $4-6$ dependants and $16.9 \%$ had no dependants while $11.5 \%$ of the participants had $5+$ dependants.

This research finding shows that most of the respondents had dependants and relative families to take care of. This shows that even though the youth were many, they also had responsibilities. So however productive they could be, the dependants drained them a sign that there could be economical challenges.

\subsubsection{Level of Education}

Out of 135 participants, $34.9 \%$ of the respondents were Degree holders, $22.9 \%$ of the respondents were Diploma holders, $16.9 \%$ of the participants had certificates and $13.9 \%$ were had studied up to secondary level while the remaining $11.6 \%$ of the respondents had studied up to Primary level.

This implied that the result of the study can be relied on since majority of the respondents were educated at least with degrees and diplomas.

\subsubsection{Number of Years the Respondents Had Stayed in Juba County}

Out of 103 participants, $63.1 \%$ had stayed in Juba County for $6+$ years, $22.4 \%$ had stayed in Juba County for 4-6 years, $9.7 \%$ had stayed there for $2-4$ years and $4.8 \%$ had stayed there for 1 - 2 years and none of the respondents had been Juba County for less than a year.

This implied that the information acquired from the research was very rich and could be relied on as a big percentage of the respondents had stayed in the County and with the NGOs for a number of years.

\subsubsection{Working Experience of the Respondents}

Out of 80 participants, $31.9 \%$ had worked for the companies for 5-6 years, $27.7 \%$ had had worked for the companies for over seven years, $23.4 \%$ had worked for the companies for 3-4 years and $12.7 \%$ had worked for $1-2$ years while the remaining $4.2 \%$ had worked for less than a year.

This implied that the information acquired from the research was very rich as a big percentage of the respondents had worked with the NGOs or stayed in Juba County for good number of years.

\subsection{The Relationship between Governance and Peace Building}

Results showed a significant positive relationship between Governance and Peace building $(\mathrm{r}=0.391$, P-value $<$ 0.01). This implied that good governance which promotes good values such as participation, accountability, responsiveness, transparency and rule of law leads to effective peace building in a society.

The result is in line with Kirsti 2005 who says that Governance is another area that has to be addressed within peace building; long- term security extends beyond reforming military and police forces and is also contingent upon the conversion of warring factions into political parties that can work to manage conflicts in a manner that is conducive of positive change. And Spurk 2006 who assets that governance in peacebuilding designs requires the development of institutional capacities such as the judiciary, the electoral system, and other agencies that work to advance policy reforms, enhance transparency, and increase representation and accountability.

\subsection{The Relationship between Governance, International Communities and Peace Building}

The results indicated a significant positive relationship between Governance, International communities and Peace building $(r=0.188$, P-value $<0.01)$. This implied that good governance which advocates for good values such as participation, accountability, responsiveness, transparency and rule of law leads to effective peace building in a society; with the support from International communities, then peace building in any country can be possible.

This is in line with Orr 2002 a government is essential to providing security, justice, economic, and social functions and to channeling the will, energies, and resources of both the indigenous population and the international 
community which improve peace building in the society. Brandi, 2008 says that good governance and support from international communities increase higher chances of peace building in the society.

\subsection{The Relationship Education, International Communities and Peace Building}

Results indicated a significant positive relationship between Governance and international communities and Peace building $(r=0.188$, P-value $<0.01)$. This implied Education is the fundamental tool that makes institutional change in other sectors possible by educating personnel currently in post or those who will shape future institutions; and with the support from International communities then peace building in any country can be possible.

This is supported by Stedman, 2008 who asserts that education is an important driver of social development and with the support from international communities, can also contribute to transformations through other sectors within post-conflict societies in terms of changing behaviors and attitudes to violence, policing and the legal system; to a better understanding of the political system, how it operates and its implications for local communities.

\subsection{The Factor Structure of Governance, Education and International Communities on Peace Building}

The result shows a relationship between Governance, Education and International communities on Peace building $(\mathrm{r}=0.391,0.188,0.1888$, P-value $<0.01)$. This indicated that for peace building to be possible in any society; there must be good governance, a strategic education system and support from international communities delivered through monitoring of the peace agreement, disarmament, demobilization of ex-combatants, demilitarization and integrating human development.

Results are also consistent with the Global Monitoring Report 2011 from the United Nations Educational, Scientific and Cultural Organization (UNESCO) called for an increased role for education and governance for peace building. Similarly, the World Bank's World Development Report (WDR) 2011 recognized the important contribution to peacebuilding that the education sector and governance could make. Stedman, 2008 also believes that governance, education and international support are potentially very important drivers for supporting the transformative process in post-conflict societies.

\subsection{Factor Loadings of Governance, Education, International Communities and Peace Building}

\subsubsection{Factor Loadings of Governance}

Table above 4.10, showed the factor analysis results of Governance variable, four factors were extracted component one explains $69.66 \%$, the second shows $16.48 \%$, the third shows $11.25 \%$ and the fourth $2.99 \%$ of the variance of Governance.

The factor results of Governance under brand name attribute were explained that the government should be able to allow participation of all the citizens in all the activities $97 \%$, all stakeholders' participation helps in peace building in the society $95 \%$, that there is inclusive participation and representation of all the stakeholders $92 \%$ and that because of the government initiatives, citizens have started living together in a harmony and peaceful environment $90 \%$.

Factor results under Accountability attribute were explained that International communities have played an important role is in the disarmament, demobilization and reintegration of ex-combatants $93 \%$, International communities have strengthened opportunities for those leaving their armed groups $90 \%$ and that there has been social and economic development of the ex-combatants $87 \%$.

The Demilitarization attribute was explained that International communities have empowered civil societies $92 \%$ and that arrangements based on security to trust that can sustain peace and democracy have been made89\%.

Lastly under Integrating human development, factors were explained that dialogue between people of different faiths ethnicity can develop trust and toleration have been organized $91 \%$ and that there has been an increase of efficiency and economic sustainability, particularly for projects requiring community involvement $89 \%$ and International communities have helped in the process of empowerment and effective citizens $84 \%$.

\subsubsection{Factor loadings of Education}

Table 14showed the factor analysis results of Education variables, four factors were extracted, component one explains $62.582 \%$, the second shows $34.147 \%$, the third $2.282 \%$ and the fourth $0.988 \%$ of the variance of Education.

The factor results of Education under the Change of attitude attribute were explained that; Peoples' attitudes towards other groups have been changed and are more tolerant to each other $99 \%$, education has addressed the social and cultural issues related to fundamental freedoms within broader society $99 \%$, that education has helped the new generations understand why conflict took place and in dealing with its legacies $98 \%$.

Under Imparting positive values attribute the results were explained that; Education has imparted positive values and modes of behavior based on non-violence $90 \%$, there has been a good atmosphere of understanding, tolerance and solidarity, sharing and free exchange of useful information $83 \%$ and that there has been full participation of and empowerment of women, men and youth64\%.

While the factor analysis resultsunder Enhancing knowledge and skills attribute were explained; that education can provide protection from violence, particularly for girls97\%, education instills survival skills and knowledge such as landmine awareness and protection from HIV and AIDS

$90 \%$ and that education is also the most powerful tool to develop the economic and social skills necessary to generate sustainable livelihoods for successive generations $68 \%$. 
Lastly under Awareness about human rights attribute was that education has been aimed at increasing awareness on income and land rights $98 \%$, education has increased access to information by the population on available opportunities for increasing welfare $92 \%$ and that education has saved affected group more often than not is the women or children $83 \%$.

\subsubsection{Factor Loadings of International Communities}

Table 15showed the factor analysis results of role of International communities, three factors were extracted component one explains $75.324 \%$, the second one $17.215 \%$ and the third $7.461 \%$ of the variance of the role of International communities.

The factor analysis results of role of International communities under Monitoring of the peace agreement were explained that outside actors can assist in the monitoring of the peace agreement87\%, due to sensitizations, citizens have started living in harmony and peaceful environment $82 \%$, Sensitization programmes help in peace building in the society $79 \%$ and because of sensitization, the citizens have been able to unite after the conflict $72 \%$. Under Disarmament, Demobilization attribute, the results were explained that International communities have played an important role is in the disarmament, demobilization and reintegration of ex-combatants $83 \%$, International communities have strengthened opportunities for those leaving their armed groups $80 \%$, there has been social and economic development of the excombatants $77 \%$ and that disarmament, demobilization and reintegration is imperative in the transition from war to peace $72 \%$.

Lastly under Demilitarization, they were explained that there has been building norms and institutions that bridge the structures of wartime based on violence79\%, Arrangements based on security to trust that can sustain peace and democracy have been made $75 \%$ and International communities have empowered civil societies $73 \%$.

\subsubsection{Factor Loadings of Peace Building}

Table 16showed the factor analysis results of Peace building variables, three factors were extracted component one explains $70.691 \%$, the second shows $22.552 \%$ and the third $6.757 \%$ of the variance of Peace building.

The factor analysis results of Peace building under Top-level leadership were explained that Involvement of key political and military leaders, religious leaders always emphasize cease fire because of the involvement of NGOs $87 \%$, through the involvement of NGOs key parties always focus on high level negotiations $80 \%$, through the involvement of NGOs negotiations are always led by a highly visible single mediator78\% and that through the involvement of NGOs negotiations have always been accessed by mediators at the level of states $71 \%$.

Under Trust, they were explained that peace commissions have always been organized by NGOs for reconciliation in the societies $81 \%$, problem-solving workshops have always been organized for reconciliation $79 \%$, ethnic, religious, intellectuals and humanitarian leaders have contributed to reconciliation $73 \%$ and that Insider partial teams with the assistance of renowned local individuals in society have always been organized $69 \%$.

Lastly under Grassroots-level leadership, they were explained that community dialogues organized by NGOs have been organized to help in reconciliation and peace building in the societies $80 \%$, Projects for trauma healing have been used by NGOs in reconciliation and peace building in the societies $76 \%$, through the involvement of NGOs there have been local peace commissions for reconciliation and peace building of the societies $74 \%$ and that the population or the masses. represented by leaders of local NGOs $70 \%$.

\section{Conclusion and Recommendations}

\subsection{Introduction}

This Chapter presents conclusion, recommendations and areas for further research

\subsubsection{Conclusion}

The study on the influence of Governance, Education and International communities on Peace building was conducted. Therefore the leaders of Juba County, leaders of NGOs and religious leaders should ensure good governance with a strategic education system that aims at effecting change of attitude, imparting positive values, enhancing knowledge and skills and awareness about human rights; so that with the support of international communities which is done through monitoring of the peace agreement, disarmament, demobilization of ex-combatants, demilitarization and integrating human development, then peace building and lasting peace in Juba County and South Sudan as a whole can be achieved.

\subsection{Recommendations.}

The study on Governance, Education, International communities and Peace building of South Sudan with a particular reference of Juba County was carried out. In line with the findings and conclusions of the study, the following were recommended;

\subsubsection{The relationship between Governance and Peace building}

Results in Table 8 indicated a significant a positive relationship between Governance and Peace building $(r=0$. 391, P-value < 0.01) which implied that good governance which promotes good values such as participation, accountability, responsiveness, transparency and rule of law leads to effective peace building in a society. 
Results indicated that good governance in the society promotes peace building and so leaders in Juba county and South Sudan as a whole, should try to embrace a democratic governance that which promotes good values such as participation, accountability, responsiveness, transparency and rule of law leads to effective peace building in a society so as to build sustainable peace.

\subsubsection{The Relationship between Governance, International Communities and Peace Building}

Results showed a significant positive relationship between Governance and Peace building $(r=0.391$, P-value $<$ 0.01) which implied that good governance which promotes good values such as participation, accountability, responsiveness, transparency and rule of law leads to effective peace building in a society.

In post-conflict societies, it is much advocated by the international community that democratic systems provides the best mechanisms for reconciliation and are the best guarantors of lasting peace. And so to combat hostility, the international community must commit in providing capacity building, foreign aid, demobilization of the military forces and institutional reform.

\subsubsection{The Relationship between Education, International Communities and Peace Building}

Results indicated a significant positive relationship between Governance and international communities and Peace building $(\mathrm{r}=0.188$, P-value $<0.01)$ which implied that Education is a fundamental tool that makes institutional change in other sectors possible by educating personnel currently in post or those who will shape future institutions; and with the support from International communities then peace building in any country can be possible.

- International communities should aim at empowering with education values and promoting an electoral process that serves the purpose of national renewal and peace commitment, involvement and allocation of resources. And to promote an electoral process that serves the purposes of national renewal and peace the commitment of the international community is imperative as questions of how to address peace-building and electoral assistance have received extensive attention.

\subsubsection{The Factor Structure on Governance, Education and International Communities on Peace Building}

The result shows a relationship between Governance, Education and International communities on Peace building ( $r=0.391,0.188,0.1888$, P-value $<0.01$ ) which indicated that for peace building to be possible in any society, there must be good governance, a strategic education system and support from international community's delivered through monitoring of the peace agreement, disarmament, demobilization of ex-combatants, demilitarization and integrating human development.

- International communities should promote and advocate for a democratic governance and an effective education system. Peace building should be about supporting the transformative processes and these changes should unfold over generations. Developments through the education sector represent a very important part of this transformative process, with huge potential to impact positively or negatively because education sector is potentially a very important sector for supporting the transformative process in post-conflict societies

\subsection{Areas of Further Research}

The study recommends further study on

- Future research, inclusive of more counties in a broader geographical location as this would provide a much richer and more generalizable foundation for understanding this complex issue of peace building.

\section{Acknowledgement}

First, I would like to express my sincere gratitude and appreciation to our almighty God for enabling and guiding me through my academic life. My vote of thanks goes to my supervisor, who patiently guided me throughout the entire work.

I am grateful to Cavendish University Uganda for the academic enrichment they have offered me through their MIRD program.

Special thanks also go to the employees of UNDP, UNICEF and UNHCR, South Sudan and community members of Juba County for sparing their time for interviews and to fill in questionnaires, without them, this research would not have been done. I once again thank all, including the categories not mentioned above, who encouraged and contributed to the completion of this work.

$\begin{array}{lc}\text { 8. List of Acronyms } \\ \text { CPA } & \text { Comprehensive Peace Agreement } \\ \text { DDR } & \text { Disarmament, Demobilization and Reintegration } \\ \text { CSOs } & \text { Civil Society Organizations } \\ \text { CVI } & \text { Content Validity Index } \\ \text { EU } & \text { European Union } \\ \text { IDPs } & \text { Internally Displaced Persons } \\ \text { IGOs } & \text { Inter-Governmental Organizations } \\ \text { NGOs } & \text { Non-Governmental Organizations } \\ \text { UN } & \text { United Nations } \\ \text { UNDP } & \text { United Nations Development Programme }\end{array}$




\section{References}

i. Amara, M. et al., 'A New Bilingual Education in the Conflict-Ridden Israeli Reality', Language and Education, vol. 23, no. 1, 2009, pp. 15-35.

ii. Annan, J., and M. Brier, 'The Risk of Return: Intimate partner violence in Northern Uganda's armed conflict', Social Science and Medicine, vol. 70, no. 1, 2010, pp. 152-159.

iii. Andy Carl (2003). Kacoke Madit Peace Initiative for Acholiland, Available at: http://www.cr.org/progs/uganda.shtml8

iv. Apple, M. W., Ideology and Curriculum, Routledge Falmer, New York, 2000.

v. Bar-Tal, D., and A. S. Harel, 'Teachers as Agents of Political Influence in the Israeli High Schools', Teaching and Teacher Education vol. 18, 2002, pp. 121-134.

vi. Barnett M., H. Kim, M. O’Donnell and L. Sitea, 2007 'Peacebuilding: What is in a name?' Global Governance, vol. 13, no. 1, January-March 2007.

vii. Bloomfield, D. (2006). On good terms'; Rarifying reconciliation Report 14. Berlin:

viii. Buckland, P., Reshaping the Future: Education and post conflict reconstruction, World Bank, Washington, D.C., 2004.

ix. Burde, D., and L. L. Linden, 'The Effect of Proximity on School Enrollment: Evidence from a randomized controlled trial in Afghanistan', May 2009, available at http://sticerd.lse.ac.uk/seminarpapers/dg11052009.pdf.

x. Amara, M., Azaiza, F., Hertz-Lazarowitz, R. and Mor-Sommerfeld, A. (2009) A New Bilingual Education in the Conflict-Ridden Israeli Reality, Language and Education, 23 (1): 15-35.

xi. Barakat, B., Karpinska, Z., and Paulson, J. (2008) INEE Desk study: Education and fragility. Oxford, UK: Conflict and Education Research Group (CERG).

xii. Boutros-Ghali, B. (1992) An Agenda for Peace: Preventive Diplomacy, Peacemaking and Peace-keeping Document A/47/277 - S/241111, 17 June 1992, New York: Department of Public Information, United Nations. http://www.un.org/Docs/SG/agpeace.html

xiii. Buckland, P. (2005) Reshaping the future: Education and postconflict reconstruction. Washington, DC: The World Bank.

xiv. Bush, K., and Salterelli, D. (Eds.). (2000). The two faces of education in ethnic conflict. Florence: UNICEF Innocenti Research Centre.

xv. Cole, E.A. (2007) Teaching the Violent Past. History Education and Reconciliation, Plymouth, Rowman and Littlefield Publishers.

xvi. Colenso, P. (2005) Achieving the education Millennium Development Goals in fragie states - what is the role of aid? Brighton, UK: University of Sussex.

xvii. Coletta, N.J. \& Cullen, M.L. (2000) Violent Conflict and the Transformation of Social Capital: Lessons from Cambodia, Rwanda, Guatemala and Somalia, World Bank, Washington D.C.

xviii. Connolly, P., Smith.

xix. Ben-Porath, S.R. (2006) Citizenship Under Fire. Democratic Education in Times of Conflict, Princeton, New Jersey: Princeton University Press.

xx. Call, C., 'Institutionalizing Peace: A review of post-conflict concepts and issues for DPA', Consultant report, 31 January 2005. On International Cooperation for the UK Department for International Development, New York.

xxi. Cheru, F., 'The Highly Indebted Poor Countries (HIPC) Initiative: A human rights assessment of the PRSP', report submitted to the Commission on Human Rights, 2001.

xxii. Davies, L., Educating against Extremism, Trentham, Stroke-on-Trent, 2008.

xxiii. Del Felice, C (2008). Youth making a difference: examples of youth playing a role in bringing together divided communities. Paper presented on conference about the potential of youth to build peace in a multicultural society from 16-17 May, 2008, European university Cyprus: Unpublished.

xxiv. Education for All - Fast-Track Initiative, Education and Financing Strategies for Fragile States, World Bank, Washington, D.C., 2008.

xxv. Gurr, Ted and Barbara Harff. (2009). Internal Wars and Failures of Governance, 1954-1996, Technical Report, State Failure Task Force.

xxvi. Hassan, Sh., Johnson, P., Joqombe, A., \& Menkhaus, K., (2009). The search for peace: A history of mediation in Somalia since 1988. Mogadishu: Center for Research and Dialogue.

xxvii. Joes, Anthony James (2004). Resisting Rebellion: The History and Politics of Counterinsurgency. University Press of Kentucky.

xxviii. Murphy, Colleen (2010). A Moral Theory of Political Reconciliation, Cambridge University Press, 214pp., $\$ 85.00$ (hbk), ISBN 9780521193924.

xxix. Machel, G., UN Study on the Impact of Armed Conflict on Children, UNICEF, New York, 1996. Magill, C., Education and Fragility in Bosnia and Herzegovina', UNESCO, Paris, 2010.

xxx. Papagianni, K., The Role of Political and Development Actors in Mediation Processes,

xxxi. Centre for Humanitarian Dialogue, Geneva, 2009. 
xxxii. Smith, A., and T. Vaux, 'Education, Conflict, and International Development', Department of International Development, London, 2003.

xxxiii. Tawil, S., and A. Harley, eds., Education, Conflict and Social Cohesion, UNESCO International Bureau of Education, Geneva, 2004.

xxxiv. United Nations Children's Fund, A Human Rights-Based Approach to Education, UNICEF, New York, 2007.

xxxv. United Nations Children's Fund, Child Friendly Schools Manual, UNICEF, New York, 2009 (draft).

xxxvi. Sambaing, N., 'Short-Term and Long-Term Effects of United Nations Peace Operations', The World Bank Economic Review, vol. 22, no. 1, 2008.

\section{Appendix}

\section{Questionnaire}

\section{Community Member's Questionnaire}

Dear Sir/ Madam

I am Gabriel Alier a student at Cavendish University Uganda pursuing a Master's degree in International relation and Diplomacy. As part of the requirements for the award of the above degree, I am required to carry out a research project. The research is on governance, Education and International communities on Peace building in South Sudan. You are kindly requested to spare some time and voluntarily respond to the following questions. All your responses will be treated confidentially and will be used for academic purposes.

Your input is highly appreciated.

\section{Please Tick Your Selected Option}

\section{Section A: Biodata}

1. Gender

\begin{tabular}{|l|l|}
\hline Male & Female \\
\hline 1 & 2 \\
\hline & \\
\hline
\end{tabular}

\section{Age Group}

\begin{tabular}{|l|l|l|l|}
\hline $21-30$ Yrs & $31-40$ Yrs & $41-50$ Yrs & $50+$ Yrs \\
\hline & & & \\
\hline
\end{tabular}

\section{Marital status}

\begin{tabular}{|l|l|l|l|c|}
\hline Single & Married & Divorced & Separated & Others \\
\hline 1 & 2 & 3 & 4 & 5 \\
\hline & & & & \\
\hline
\end{tabular}

4. Number of biological children

\begin{tabular}{|l|l|l|l|}
\hline 0 & $1-3$ & $4-5$ & $5+$ \\
\hline & & & \\
\hline
\end{tabular}

5. Number of dependants

\begin{tabular}{|l|l|l|l|}
\hline 0 & $1-3$ & $4-5$ & $5+$ \\
\hline & & & \\
\hline
\end{tabular}

6. Number of years spent working in Juba County

\begin{tabular}{|l|l|l|l|l|}
\hline$<1$ year & $1-2$ Yrs & $2-4$ Yrs & $4-6$ Yrs & $6+$ Yrs \\
\hline & & & & \\
\hline
\end{tabular}

\section{Level of education}

\begin{tabular}{|c|l|l|l|l|l|}
\hline $\begin{array}{c}\text { None } \\
1\end{array}$ & $\begin{array}{c}\text { Primary } \\
2\end{array}$ & $\begin{array}{c}\text { Secondary } \\
3\end{array}$ & $\begin{array}{c}\text { Certificate } \\
4\end{array}$ & Tertiary & Masters \\
\hline & & & & 5 & 6 \\
\hline
\end{tabular}




\begin{tabular}{|c|c|c|c|c|c|c|}
\hline & $\begin{array}{l}\text { Please indicate the degree to which you agree with the } \\
\text { following statements. Tick the scale }\end{array}$ & 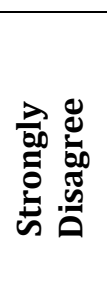 & 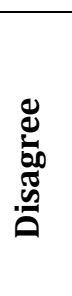 & 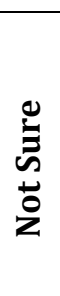 & 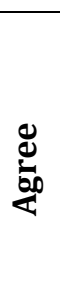 & 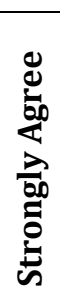 \\
\hline & & 1 & 2 & 3 & 4 & 5 \\
\hline & Participation & & & & & \\
\hline 1 & $\begin{array}{l}\text { There is inclusive participation and representation of all the } \\
\text { stakeholders }\end{array}$ & & & & & \\
\hline 2 & $\begin{array}{l}\text { Government should be able to allow participation of all the } \\
\text { citizens in all the activities. }\end{array}$ & & & & & \\
\hline 3 & $\begin{array}{l}\text { Because of the government initiatives, citizens have started } \\
\text { living together in a harmony and peaceful environment }\end{array}$ & & & & & \\
\hline 4 & $\begin{array}{l}\text { The government does not allow citizens to be involved in } \\
\text { development programmes }\end{array}$ & & & & & \\
\hline 5 & $\begin{array}{l}\text { All stakeholders' participation helps in peace building in the } \\
\text { society }\end{array}$ & & & & & \\
\hline & Accountability & & & & & \\
\hline 6 & $\begin{array}{l}\text { International communities have played an important role is in } \\
\text { the disarmament, demobilization and reintegration of ex- } \\
\text { combatants. }\end{array}$ & & & & & \\
\hline 7 & $\begin{array}{l}\text { Disarmament, demobilization and reintegration is imperative in } \\
\text { the transition from war to peace }\end{array}$ & & & & & \\
\hline 8 & allows peaceful social and economic activities to resume & & & & & \\
\hline 9 & $\begin{array}{l}\text { International communities have strengthened opportunities } \\
\text { for those leaving their armed groups. }\end{array}$ & & & & & \\
\hline 10 & $\begin{array}{l}\text { There has been social and economic development of the ex- } \\
\text { combatants }\end{array}$ & & & & & \\
\hline & Demilitarization & & & & & \\
\hline 11 & $\begin{array}{l}\text { There has been building norms and institutions that bridge the } \\
\text { structures of wartime based on violence }\end{array}$ & & & & & \\
\hline 12 & $\begin{array}{l}\text { Arrangements based on security to trust that can sustain peace } \\
\text { and democracy have been made }\end{array}$ & & & & & \\
\hline 13 & There has been freedom to political parties & & & & & \\
\hline 14 & There has been freedom to open economies & & & & & \\
\hline 15 & International communities have empowered civil societies & & & & & \\
\hline & Integrating Human Development & & & & & \\
\hline 16 & $\begin{array}{l}\text { International communities have contributed to the } \\
\text { strengthening of civil society, civil culture and social capital }\end{array}$ & & & & & \\
\hline 17 & $\begin{array}{l}\text { International communities have strengthened democracy and } \\
\text { enabled conflict resolution. }\end{array}$ & & & & & \\
\hline 18 & $\begin{array}{l}\text { Dialogue between people of different faiths ethnicity can } \\
\text { develop trust and toleration have been organized }\end{array}$ & & & & & \\
\hline 19 & $\begin{array}{l}\text { International communities have helped in the process of } \\
\text { empowerment and effective citizens. }\end{array}$ & & & & & \\
\hline 20 & $\begin{array}{l}\text { There has been an increase of efficiency and economic } \\
\text { sustainability, particularly for projects requiring community } \\
\text { involvement }\end{array}$ & & & & & \\
\hline
\end{tabular}

Table 18 


\begin{tabular}{|c|c|c|c|c|c|c|}
\hline & $\begin{array}{l}\text { Please indicate the degree to which you agree with the following } \\
\text { statements. Tick the scale }\end{array}$ & 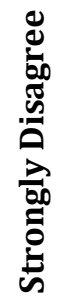 & 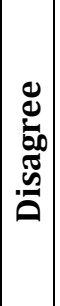 & 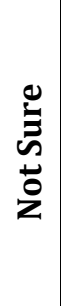 & 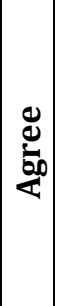 & 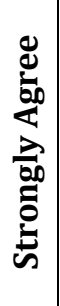 \\
\hline & & 1 & 2 & 3 & 4 & 5 \\
\hline & Change of Attitude & & & & & \\
\hline 1 & $\begin{array}{l}\text { Peoples' attitudes towards other groups have been changed and are } \\
\text { more tolerant to each other }\end{array}$ & & & & & \\
\hline 2 & $\begin{array}{l}\text { Education has addressed the social and cultural issues related to } \\
\text { fundamental freedoms within broader society }\end{array}$ & & & & & \\
\hline 3 & structural inequalities are also addressed & & & & & \\
\hline 4 & $\begin{array}{l}\text { Education has addressed has identified the underlying causes for conflict } \\
\text { related to social justice }\end{array}$ & & & & & \\
\hline 5 & $\begin{array}{l}\text { Education has helped the new generations understand why conflict took } \\
\text { place and in dealing with its legacies }\end{array}$ & & & & & \\
\hline 6 & $\begin{array}{l}\text { There is independence of the media and media independence, religious } \\
\text { freedoms and attitudes }\end{array}$ & & & & & \\
\hline & Imparting Positive Values & & & & & \\
\hline 7 & $\begin{array}{l}\text { Education has imparted positive values and modes of behavior based on } \\
\text { non-violence }\end{array}$ & & & & & \\
\hline 8 & There has been respect for fundamental human rights & & & & & \\
\hline 9 & $\begin{array}{l}\text { There has been full participation of and empowerment of women, men } \\
\text { and youth }\end{array}$ & & & & & \\
\hline 10 & $\begin{array}{l}\text { There has been a good atmosphere of understanding, tolerance and } \\
\text { solidarity, sharing and free exchange of useful information, }\end{array}$ & & & & & \\
\hline 11 & $\begin{array}{l}\text { Nonviolent means of managing conflict and the replacement of violent } \\
\text { competition with cooperation has been done }\end{array}$ & & & & & \\
\hline & Enhancing Knowledge and Skills & & & & & \\
\hline 11 & Education can provide protection from violence, particularly for girls & & & & & \\
\hline 12 & $\begin{array}{l}\text { Schools have been helping in protecting people from more recruitment } \\
\text { and exploitation }\end{array}$ & & & & & \\
\hline 13 & $\begin{array}{l}\text { Education instills survival skills and knowledge such as landmine } \\
\text { awareness and protection from HIV and AIDS }\end{array}$ & & & & & \\
\hline 14 & $\begin{array}{l}\text { Education provides opportunities for psychological, emotional and } \\
\text { cognitive development }\end{array}$ & & & & & \\
\hline \multirow[t]{2}{*}{15} & $\begin{array}{l}\text { Education is also the most powerful tool to develop the economic and } \\
\text { social skills necessary to generate sustainable livelihoods for successive } \\
\text { generations }\end{array}$ & & & & & \\
\hline & Awareness about Human Rights & & & & & \\
\hline 21 & $\begin{array}{l}\text { Education has been aimed at sensitizing women and the whole } \\
\text { community on recognizing and enforcing their human rights }\end{array}$ & & & & & \\
\hline 22 & $\begin{array}{l}\text { Education has increased access to information by the population on } \\
\text { available opportunities for increasing welfare }\end{array}$ & & & & & \\
\hline 23 & The society is aware of their human rights & & & & & \\
\hline 24 & $\begin{array}{l}\text { Education has been aimed at increasing awareness on income and land } \\
\text { rights. }\end{array}$ & & & & & \\
\hline 25 & $\begin{array}{l}\text { Education has saved affected group more often than not is the women or } \\
\text { children }\end{array}$ & & & & & \\
\hline
\end{tabular}

Table 19 


\begin{tabular}{|c|c|c|c|c|c|c|}
\hline & $\begin{array}{l}\text { Please indicate the degree to which you agree with the following } \\
\text { statements. Tick the scale }\end{array}$ & 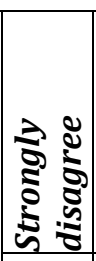 & 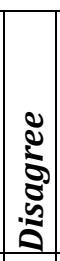 & 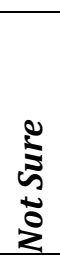 & 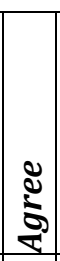 & 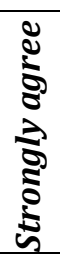 \\
\hline & & 1 & 2 & 3 & 4 & 5 \\
\hline & Monitoring of the peace agreement & & & & & \\
\hline 1 & Outside actors can assist in the monitoring of the peace agreement & & & & & \\
\hline 2 & $\begin{array}{l}\text { Because of sensitization, the citizens have been able to unite after the } \\
\text { conflict }\end{array}$ & & & & & \\
\hline 3 & $\begin{array}{l}\text { Due to sensitizations, citizens have started living in harmony and } \\
\text { peaceful environment }\end{array}$ & & & & & \\
\hline 4 & There are no sensitization programmes in the county & & & & & \\
\hline \multirow[t]{2}{*}{5} & Sensitization programmes help in peace building in the society & & & & & \\
\hline & Disarmament, Demobilization & & & & & \\
\hline 6 & $\begin{array}{l}\text { International communities have played an important role is in the } \\
\text { disarmament, demobilization and reintegration of ex-combatants. }\end{array}$ & & & & & \\
\hline 7 & $\begin{array}{l}\text { Disarmament, demobilization and reintegration is imperative in the } \\
\text { transition from war to peace }\end{array}$ & & & & & \\
\hline 8 & allows peaceful social and economic activities to resume & & & & & \\
\hline 9 & $\begin{array}{l}\text { International communities have strengthened opportunities for those } \\
\text { leaving their armed groups. }\end{array}$ & & & & & \\
\hline \multirow[t]{2}{*}{10} & There has been social and economic development of the ex-combatants & & & & & \\
\hline & Demilitarization & & & & & \\
\hline 11 & $\begin{array}{l}\text { There has been building norms and institutions that bridge the } \\
\text { structures of wartime based on violence }\end{array}$ & & & & & \\
\hline 12 & $\begin{array}{l}\text { Arrangements based on security to trust that can sustain peace and } \\
\text { democracy have been made }\end{array}$ & & & & & \\
\hline 13 & There has been freedom to political parties & & & & & \\
\hline 14 & There has been freedom to open economies & & & & & \\
\hline \multirow[t]{2}{*}{15} & International communities have empowered civil societies & & & & & \\
\hline & Integrating human development & & & & & \\
\hline 21 & $\begin{array}{l}\text { International communities have contributed to the strengthening of } \\
\text { civil society, civil culture and social capital }\end{array}$ & & & & & \\
\hline 22 & $\begin{array}{l}\text { International communities have strengthened democracy and enabled } \\
\text { conflict resolution. }\end{array}$ & & & & & \\
\hline 23 & $\begin{array}{l}\text { Dialogue between people of different faiths ethnicity can develop trust } \\
\text { and toleration have been organized }\end{array}$ & & & & & \\
\hline 24 & $\begin{array}{l}\text { International communities have helped in the process of empowerment } \\
\text { and effective citizens. }\end{array}$ & & & & & \\
\hline 25 & $\begin{array}{l}\text { There has been an increase of efficiency and economic sustainability, } \\
\text { particularly for projects requiring community involvement }\end{array}$ & & & & & \\
\hline
\end{tabular}

Table 20 


\begin{tabular}{|c|c|c|c|c|c|c|}
\hline & $\begin{array}{l}\text { To what extent do you agree with the } \\
\text { following statements? Tick the scale }\end{array}$ & 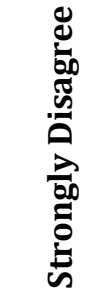 & 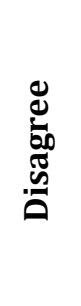 & $\begin{array}{l}0 \\
\vdots \\
\dot{\omega} \\
\stackrel{0}{z} \\
z\end{array}$ & 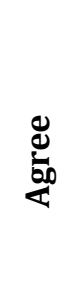 & 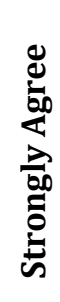 \\
\hline & & 1 & 2 & 3 & 4 & 5 \\
\hline & Top-level Leadership & & & & & \\
\hline 1 & $\begin{array}{l}\text { There has been involvement of key political and } \\
\text { military leaders, religious leaders with a high } \\
\text { visibility in the conflict in peace building. }\end{array}$ & & & & & \\
\hline 2 & $\begin{array}{l}\text { These key parties always focus on high level } \\
\text { negotiations }\end{array}$ & & & & & \\
\hline 3 & $\begin{array}{l}\text { Involvement of key political and military leaders, } \\
\text { religious leaders always emphasize cease fire }\end{array}$ & & & & & \\
\hline 4 & $\begin{array}{l}\text { Negotiations are always led by a highly visible } \\
\text { single mediator }\end{array}$ & & & & & \\
\hline 5 & $\begin{array}{l}\text { Such negotiation has always been accessed by } \\
\text { mediation at the level of states }\end{array}$ & & & & & \\
\hline & Middle-level leadership & & & & & \\
\hline 6 & $\begin{array}{l}\text { Ethnic, religious, intellectuals and humanitarian } \\
\text { leaders who are highly respected in society have } \\
\text { always been involved in the negotiations and } \\
\text { peace building. }\end{array}$ & & & & & \\
\hline 7 & $\begin{array}{l}\text { Problem-solving workshops have always been } \\
\text { organized for reconciliation in the societies. }\end{array}$ & & & & & \\
\hline 8 & $\begin{array}{l}\text { Peace commissions have always been organized } \\
\text { for reconciliation in the societies. }\end{array}$ & & & & & \\
\hline 9 & $\begin{array}{l}\text { Insider partial teams with the assistance of } \\
\text { renowned local individuals in society have } \\
\text { always been organized for reconciliation and } \\
\text { peace building }\end{array}$ & & & & & \\
\hline 10 & $\begin{array}{l}\text { Ethnic, religious, intellectuals and humanitarian } \\
\text { leaders have contributed to reconciliation and } \\
\text { peace building in the post conflict transitioning } \\
\text { societies. }\end{array}$ & & & & & \\
\hline & Grassroots-level leadership & & & & & \\
\hline 11 & $\begin{array}{l}\text { The population or the masses represented by } \\
\text { leaders of local NGOs or a refugee camp and local } \\
\text { health officials have been involved in } \\
\text { reconciliation and peace building of the societies. }\end{array}$ & & & & & \\
\hline 12 & $\begin{array}{l}\text { There have been local peace commissions for } \\
\text { reconciliation and peace building of the societies. }\end{array}$ & & & & & \\
\hline 13 & $\begin{array}{l}\text { Community dialogues have been organized to } \\
\text { help in reconciliation and peace building in the } \\
\text { societies. }\end{array}$ & & & & & \\
\hline 14 & $\begin{array}{l}\text { Projects for trauma healing have been used in } \\
\text { reconciliation and peace building in the societies. }\end{array}$ & & & & & \\
\hline 15 & $\begin{array}{l}\text { There is sensitization of the masses for prejudice } \\
\text { reduction and psychological work in post war } \\
\text { trauma. }\end{array}$ & & & & & \\
\hline
\end{tabular}

Table 21 


\section{Questionnaire}

\section{Ngo's Staff Questionnaire}

Dear Sir/ Madam

I am Gabriel Alier Riak a student at Cavendish University Uganda pursuing a Master's degree in International relation and Diplomacy. As part of the requirements for the award of the above degree, I am required to carry out a research project. The research is on governance, Education and International communities on Peace building in South Sudan. You are kindly requested to spare some time and voluntarily respond to the following questions. All your responses will be treated confidentially and will be used for academic purposes.

Your input is highly appreciated.

\section{Please tick your selected option}

\section{Section A: $\quad$ Biodata}

1. Gender

\begin{tabular}{|l|l|}
\hline Male & Female \\
\hline 1 & 2 \\
\hline & \\
\hline
\end{tabular}

2. Age Group

\begin{tabular}{|l|l|l|l|}
\hline $21-30$ Yrs & $31-40$ Yrs & $41-50$ Yrs & $50+$ Yrs \\
\hline & & & \\
\hline
\end{tabular}

3. Marital status

\begin{tabular}{|l|l|l|l|c|}
\hline Single & Married & Divorced & Separated & Others \\
\hline 1 & 2 & 3 & 4 & 5 \\
\hline & & & & \\
\hline
\end{tabular}

6. Number of years spent working in Juba County

\begin{tabular}{|l|l|l|l|l|}
\hline$<1$ year & $1-2$ Yrs & $2-4$ Yrs & $4-6$ Yrs & $6+$ Yrs \\
\hline
\end{tabular}

\section{Level of education}

\begin{tabular}{|c|l|l|l|l|l|}
\hline $\begin{array}{c}\text { None } \\
1\end{array}$ & $\begin{array}{c}\text { Primary } \\
2\end{array}$ & $\begin{array}{c}\text { Secondary } \\
3\end{array}$ & $\begin{array}{c}\text { Certificate } \\
4\end{array}$ & Tertiary & Masters \\
\hline & & & & 5 & 6 \\
\hline
\end{tabular}

\section{Section B: Governance}

\begin{tabular}{|c|c|c|c|c|c|c|}
\hline & $\begin{array}{l}\text { Please indicate the degree to which you agree with the } \\
\text { following statements. Tick the scale }\end{array}$ & 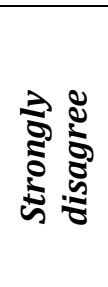 & 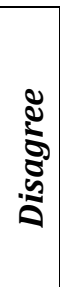 & 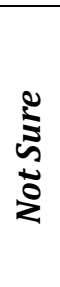 & 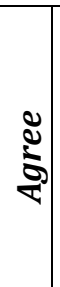 & 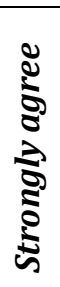 \\
\hline & & 1 & 2 & 3 & 4 & 5 \\
\hline & Participation & & & & & \\
\hline 1 & $\begin{array}{l}\text { There is inclusive participation and representation of NGOs } \\
\text { in Peace Building in South Sudan }\end{array}$ & & & & & \\
\hline 2 & $\begin{array}{l}\text { Government should be able to allow participation of all } \\
\text { NGOs and the citizens in all the activities intended for peace } \\
\text { Building in South Sudan. }\end{array}$ & & & & & \\
\hline 3 & $\begin{array}{l}\text { Because of the government initiatives that involve NGOs, } \\
\text { citizens have started living together in a harmony and }\end{array}$ & & & & & \\
\hline
\end{tabular}




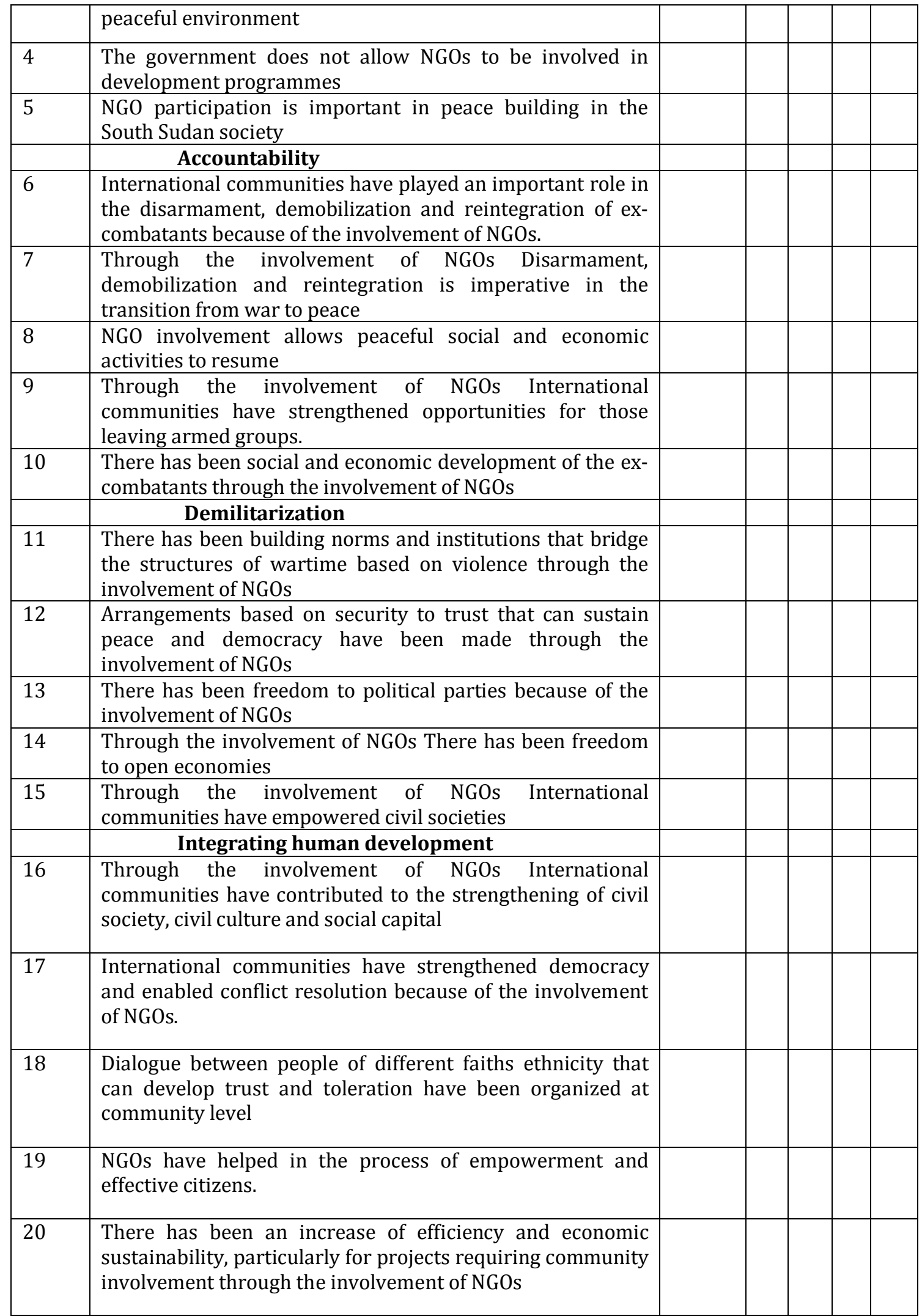

Table 22 


\section{Section C: Education}

\begin{tabular}{|c|c|c|c|c|c|c|}
\hline & $\begin{array}{l}\text { Please indicate the degree to which you agree with the } \\
\text { following statements. Tick the scale }\end{array}$ & 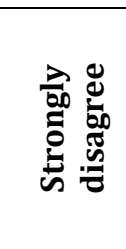 & 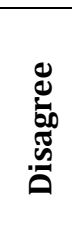 & $\begin{array}{l}\stackrel{0}{\vdots} \\
\tilde{n} \\
\stackrel{2}{0} \\
z\end{array}$ & 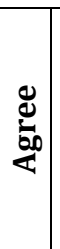 & 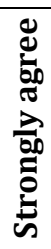 \\
\hline & & 1 & 2 & 3 & 4 & 5 \\
\hline & Change of attitude & & & & & \\
\hline 1 & $\begin{array}{l}\text { Peoples' attitudes towards other groups have been changed and are } \\
\text { more tolerant to each other through the involvement of NGOs }\end{array}$ & & & & & \\
\hline 2 & $\begin{array}{l}\text { Education has addressed the social and cultural issues related to } \\
\text { fundamental freedoms within broader society through the } \\
\text { involvement of NGOs }\end{array}$ & & & & & \\
\hline 3 & $\begin{array}{l}\text { structural inequalities are also addressed through the involvement of } \\
\text { NGOs }\end{array}$ & & & & & \\
\hline 4 & $\begin{array}{l}\text { Education has addressed has identified the underlying causes for } \\
\text { conflict related to social justice through the involvement of NGOs }\end{array}$ & & & & & \\
\hline 5 & $\begin{array}{l}\text { Education has helped the new generations understand why conflict } \\
\text { took place and in dealing with its legacies through the involvement of } \\
\text { NGOs }\end{array}$ & & & & & \\
\hline 6 & $\begin{array}{l}\text { There is independence of the media and media independence, } \\
\text { religious freedoms and attitudes through the involvement of NGOs }\end{array}$ & & & & & \\
\hline & Imparting positive values & & & & & \\
\hline 7 & $\begin{array}{l}\text { Education has imparted positive values and modes of behavior based } \\
\text { on non-violence through the involvement of NGOs }\end{array}$ & & & & & \\
\hline 8 & $\begin{array}{l}\text { There has been respect for fundamental human rights because of the } \\
\text { involvement of NGOs }\end{array}$ & & & & & \\
\hline 9 & $\begin{array}{l}\text { There has been full participation of and empowerment of women, } \\
\text { men and youth because of the involvement of NGOs }\end{array}$ & & & & & \\
\hline 10 & $\begin{array}{l}\text { There has been a good atmosphere of understanding, tolerance and } \\
\text { solidarity, sharing and free exchange of useful information because of } \\
\text { the involvement of NGOs }\end{array}$ & & & & & \\
\hline \multirow[t]{2}{*}{11} & $\begin{array}{l}\text { Nonviolent means of managing conflict and the replacement of violent } \\
\text { competition with cooperation has been done because of the } \\
\text { involvement of NGOs }\end{array}$ & & & & & \\
\hline & Enhancing knowledge and skills & & & & & \\
\hline 11 & $\begin{array}{l}\text { Education can provide protection from violence, particularly for girls } \\
\text { through the involvement of NGOs }\end{array}$ & & & & & \\
\hline 12 & $\begin{array}{l}\text { Through the involvement of NGOs Schools have been helping in } \\
\text { protecting people from more recruitment and exploitation }\end{array}$ & & & & & \\
\hline 13 & $\begin{array}{l}\text { Education instills survival skills and knowledge such as landmine } \\
\text { awareness and protection from HIV and AIDS if NGOs are involved in } \\
\text { the process }\end{array}$ & & & & & \\
\hline 14 & $\begin{array}{l}\text { Education provides opportunities for psychological, emotional and } \\
\text { cognitive development }\end{array}$ & & & & & \\
\hline \multirow[t]{2}{*}{15} & $\begin{array}{l}\text { Education is also the most powerful tool to develop the economic and } \\
\text { social skills necessary to generate sustainable livelihoods for } \\
\text { successive generations }\end{array}$ & & & & & \\
\hline & Awareness about human rights & & & & & \\
\hline 21 & $\begin{array}{l}\text { Through the involvement of NGOs Education has been focused on } \\
\text { sensitizing women and the whole community on recognizing and } \\
\text { enforcing their human rights }\end{array}$ & & & & & \\
\hline 22 & $\begin{array}{l}\text { Through the involvement of NGOs Education has increased access to } \\
\text { information by the population on available opportunities for } \\
\text { increasing welfare }\end{array}$ & & & & & \\
\hline 23 & $\begin{array}{l}\text { Through the involvement of NGOsthe society is aware of their human } \\
\text { rights }\end{array}$ & & & & & \\
\hline 24 & $\begin{array}{l}\text { Through the involvement of NGOs Education has been focused at } \\
\text { increasing awareness on income and land rights. }\end{array}$ & & & & & \\
\hline 25 & $\begin{array}{l}\text { Education has saved affected groups more often the women or } \\
\text { children because of the involvement of NGOs }\end{array}$ & & & & & \\
\hline
\end{tabular}

\section{Table 23}




\section{Section D: International Communities}

\begin{tabular}{|c|c|}
\hline & $\begin{array}{l}\text { Please indicate the degree to which you agree with the following statements. } \\
\text { Tick the scale }\end{array}$ \\
\hline & Monitoring of the peace agreement \\
\hline 1 & $\begin{array}{l}\text { Through the involvement of NGOs outside actors can assist in the monitoring of the } \\
\text { peace agreement }\end{array}$ \\
\hline 2 & $\begin{array}{l}\text { Through the involvement of NGOs in sensitization, the citizens have been able to unite } \\
\text { after the conflict }\end{array}$ \\
\hline 3 & $\begin{array}{l}\text { through the involvement of NGOs in sensitizations, citizens have started living in } \\
\text { harmony and peaceful environment }\end{array}$ \\
\hline 4 & There are no sensitization programmes in the county \\
\hline \multirow[t]{2}{*}{5} & Sensitization programmes help in peace building in the society \\
\hline & Disarmament, Demobilization \\
\hline 6 & $\begin{array}{l}\text { International communities have played an important role is in the disarmament, } \\
\text { demobilization and reintegration of ex-combatants because of the involvement of } \\
\text { NGOs. }\end{array}$ \\
\hline 7 & $\begin{array}{l}\text { Through the involvement of NGOs- Disarmament, demobilization and reintegration is } \\
\text { imperative in the transition from war to peace }\end{array}$ \\
\hline 8 & allows peaceful social and economic activities to resume \\
\hline 9 & $\begin{array}{l}\text { Through the involvement of NGOs, International communities have strengthened } \\
\text { opportunities for those leaving their armed groups. }\end{array}$ \\
\hline \multirow[t]{2}{*}{10} & $\begin{array}{l}\text { There has been social and economic development of the ex-combatants through the } \\
\text { involvement of NGOs }\end{array}$ \\
\hline & Demilitarization \\
\hline 11 & $\begin{array}{l}\text { There has been building norms and institutions that bridge the structures of wartime } \\
\text { based on violence because NGOs have been involved in the process }\end{array}$ \\
\hline 12 & $\begin{array}{l}\text { Through the involvement of NGOs arrangements based on security to trust that can } \\
\text { sustain peace and democracy have been made }\end{array}$ \\
\hline 13 & There has been freedom to political parties because of the involvement of NGOs \\
\hline 14 & There has been freedom to open economies because of the involvement of NGOs \\
\hline \multirow[t]{2}{*}{15} & $\begin{array}{l}\text { International communities have empowered civil societies because of the involvement } \\
\text { of NGOs }\end{array}$ \\
\hline & Integrating human development \\
\hline 16 & $\begin{array}{l}\text { International communities have contributed to the strengthening of civil society, civil } \\
\text { cultureand social capital through the involvement of NGOs }\end{array}$ \\
\hline 17 & $\begin{array}{l}\text { International communities have strengthened democracy and enabled conflict } \\
\text { resolution through the involvement of NGOs. }\end{array}$ \\
\hline 18 & $\begin{array}{l}\text { Through the involvement of NGOs dialogue between people of different faithsethnicity } \\
\text { can develop trust and toleration have been organized }\end{array}$ \\
\hline 19 & $\begin{array}{l}\text { Through the involvement of NGOs International communities have helped in the } \\
\text { process of empowerment and effective citizens. }\end{array}$ \\
\hline 20 & $\begin{array}{l}\text { There has been an increase of efficiency and economic sustainability, particularly for } \\
\text { projects requiring community involvement because of the involvement of NGOs in } \\
\text { peace building }\end{array}$ \\
\hline
\end{tabular}

Table 24 


\section{Section E: Peace Building}

\begin{tabular}{|c|c|c|c|c|c|c|}
\hline & \multirow[t]{2}{*}{$\begin{array}{l}\text { To what extent do you agree with the following } \\
\text { statements? Tick the scale }\end{array}$} & 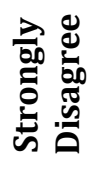 & 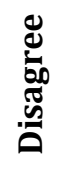 & 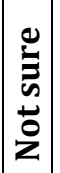 & 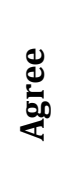 & 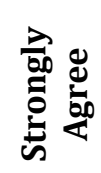 \\
\hline & & 1 & 2 & 3 & 4 & 5 \\
\hline & Top-level leadership & & & & & \\
\hline 1 & $\begin{array}{l}\text { There has been involvement of key political and military } \\
\text { leaders, religious leaders with a high visibility in the } \\
\text { conflict in peace building through the involvement of } \\
\text { NGOs in peace building. }\end{array}$ & & & & & \\
\hline 2 & $\begin{array}{l}\text { Through the involvement of NGOs key parties always } \\
\text { focus on high level negotiations }\end{array}$ & & & & & \\
\hline 3 & $\begin{array}{l}\text { Involvement of key political and military leaders, } \\
\text { religious leaders always emphasize cease fire because of } \\
\text { the involvement of NGOs }\end{array}$ & & & & & \\
\hline 4 & $\begin{array}{l}\text { Through the involvement of NGOs negotiations are } \\
\text { always led by a highly visible single mediator }\end{array}$ & & & & & \\
\hline 5 & $\begin{array}{l}\text { Through the involvement of NGOs negotiations have } \\
\text { always been accessed by mediators at the level of states }\end{array}$ & & & & & \\
\hline & Middle-level leadership & & & & & \\
\hline 6 & $\begin{array}{l}\text { Ethnic, religious, intellectuals and humanitarian leaders } \\
\text { who are highly respected in society have always been } \\
\text { involved in the negotiations and peace building because } \\
\text { of the involvement of NGOs. }\end{array}$ & & & & & \\
\hline 7 & $\begin{array}{l}\text { Problem-solving workshops have always been organized } \\
\text { for reconciliation in the societies by NGO groups. }\end{array}$ & & & & & \\
\hline 8 & $\begin{array}{l}\text { Peace commissions have always been organized by NGOs } \\
\text { for reconciliation in the societies. }\end{array}$ & & & & & \\
\hline 9 & $\begin{array}{l}\text { Insider partial teams with the assistance of renowned } \\
\text { local individuals in society have always been organized } \\
\text { for reconciliation and peace building }\end{array}$ & & & & & \\
\hline 10 & $\begin{array}{l}\text { Ethnic, religious, intellectuals and humanitarian leaders } \\
\text { have through NGO involvement contributed to } \\
\text { reconciliation and peace building in the post conflict } \\
\text { transitioning societies. }\end{array}$ & & & & & \\
\hline & Grassroots-level leadership & & & & & \\
\hline 11 & $\begin{array}{l}\text { The population or the masses represented by leaders of } \\
\text { local NGOs or a refugee camp and local health officials } \\
\text { have been involved in reconciliation and peace building } \\
\text { of the societies. }\end{array}$ & & & & & \\
\hline 12 & $\begin{array}{l}\text { Through the involvement of NGOs there have been local } \\
\text { peace commissions for reconciliation and peace building } \\
\text { of the societies. }\end{array}$ & & & & & \\
\hline 13 & $\begin{array}{l}\text { Community dialogues organized by NGOs have been } \\
\text { organized to help in reconciliation and peace building in } \\
\text { the societies. }\end{array}$ & & & & & \\
\hline 14 & $\begin{array}{l}\text { Projects for trauma healing have been used by NGOs in } \\
\text { reconciliation and peace building in the societies. }\end{array}$ & & & & & \\
\hline 15 & $\begin{array}{l}\text { There is sensitization of the masses by NGOs for } \\
\text { prejudice reduction and psychological work in post war } \\
\text { trauma. }\end{array}$ & & & & & \\
\hline
\end{tabular}

Table 25 
Budget Estimates

\begin{tabular}{|c|c|c|c|c|}
\hline No. & ITEM & Quantity & $\begin{array}{c}\text { Cost/Unit } \\
\text { (USSP) }\end{array}$ & Total cost \\
\hline 1. & Stationery & $1(\mathrm{ream})$ & 50 & 50 \\
\hline 2. & Printing \& Binding & - & 70 & 70 \\
\hline 3. & Communication & - & 1500 & 1500 \\
\hline 4. & Transport & - & 1000 & 1000 \\
\hline 5. & Lunch & 10 days & 50 & 500 \\
\hline 6. & Research Assistants & 2 & 700 & 1400 \\
\hline 7. & Miscellaneous & - & 1000 & 1000 \\
\hline & Data analysis & & & 500 \\
\hline & TOTAL & & & 5,720 \\
\hline
\end{tabular}

Table 26

Workplan for the Research Project

\begin{tabular}{|c|c|c|}
\hline May 2014 & $\begin{array}{c}\text { Proposal writing. Developing research } \\
\text { instruments and submission }\end{array}$ & $\begin{array}{c}\text { Researcher and } \\
\text { Supervisor }\end{array}$ \\
\hline June 2014 & Proposal review and Pilot Testing of tools & $\begin{array}{c}\text { Researcher and } \\
\text { Supervisor }\end{array}$ \\
\hline July 2014 & Data collection & Researcher \\
\hline July 2014 & Data processing and Analysis & Researcher \\
\hline August- 2014 & $\begin{array}{c}\text { Report writing and Final report } \\
\text { submission }\end{array}$ & $\begin{array}{c}\text { Researcher and } \\
\text { Supervisor }\end{array}$ \\
\hline
\end{tabular}

Table 27 